Article

\title{
Hyperspectral Alteration Information from Drill Cores and Deep Uranium Exploration in the Baiyanghe Uranium Deposit in the Xuemisitan Area, Xinjiang, China
}

\author{
Qing-Jun $\mathrm{Xu}{ }^{1}$, Fa-Wang Ye ${ }^{2}$, Shao-Feng Liu ${ }^{1, *}$, Zhi-Xin Zhang ${ }^{3}$ and Chuan Zhang ${ }^{2}$ \\ 1 State Key Laboratory of Geological Processes and Mineral Resources, School of Earth Sciences and Resources, \\ China University of Geosciences, Beijing 100083, China; kevincugb2016@163.com \\ 2 National Key Laboratory of Science and Technology on Remote Sensing Information and Image Analysis, \\ Beijing Research Institute of Uranium Geology, Beijing 100029, China; yfwbeijing2008@sina.com (F.-W.Y.); \\ chuanzi@163.com (C.Z.) \\ 3 Institute of Remote Sensing and Digital Earth Chinese Academy of Sciences, University of Chinese Academy \\ of Sciences, Beijing 100101, China; zhangzx2014@radi.ac.cn \\ * Correspondence: shaofeng@cugb.edu.cn; Tel.: +86-138-1116-3529
}

Academic Editors: Magaly Koch and Prasad S. Thenkabail

Received: 13 March 2017; Accepted: 4 May 2017; Published: 6 May 2017

\begin{abstract}
The Baiyanghe uranium deposit is a currently important medium-sized deposit in the Xuemisitan area, Xinjiang. The hydrothermal alteration in this deposit is closely related to the uranium mineralization of the deposit. In this study, hyperspectral data are collected from drill cores in the Baiyanghe uranium deposit using a FieldSpec4 visible-shortwave infrared spectrometer to study the hydrothermal alteration. The results reveal that the altered mineral assemblages have obvious zonation characteristics: (1) the upper section comprises long-wavelength illite and minor hematite and montmorillonite; (2) the middle section contains three types of illite (long-, mediumand short-wavelength illite) and hematite; and (3) the lower section includes short-wavelength illite, chlorite and carbonate. Additionally, the variety in the characteristic absorption-peak wavelength of illite at $2200 \mathrm{~nm}$ gradually shifts to shorter wavelength and ranges between $2195 \mathrm{~nm}$ and $2220 \mathrm{~nm}$ with increasing depth, while the SWIR-IC (short-wavelength infrared illite crystallinity, a dimensionless quantity) of the drill holes gradually increases from 0.2 to 2.1 . These patterns reflect the hydrothermal fluid activity in the deposit, which features relatively high-temperature, high-pressure hydrothermal fluid in the deeper section and low-temperature, low-pressure hydrothermal fluid in the shallower section. Additionally, the uranium mineralization is located near the fracture zone, which represents the center of hydrothermal fluid activity or mineralization. This area has abundant alteration minerals, and the minerals illite (short- and medium-wavelength), hematite and fluorite can be used as uranium-prospecting indicators for uranium exploration in the deeper sections of the Baiyanghe uranium deposit.
\end{abstract}

Keywords: hyperspectral; Baiyanghe uranium deposit; drill holes; illite; SWIR-IC; hydrothermal fluid

\section{Introduction}

The Baiyanghe uranium deposit is an important medium-sized deposit in Hebukesaier county, Xinjiang province, NW (northwest) China [1]. In recent years, the geochemical characteristics, fluid-inclusion characteristics, geological features and other features of the Baiyanghe uranium deposit have been investigated [2-5]. Landsat 7 and Quickbird remote-sensing images were used to interpret volcanic features in the Baiyanghe mining area by Lu et al. [6], who also analyzed the characteristics of 
the cryptovolcanic rock mass, the alteration distribution and its influences, and the possible uranium metallogenic position. An Enhanced Thematic Mapper Plus image was used by Qiu et al. [7] to map ferric iron alteration during uranium exploration in the Baiyanghe uranium deposit. Furthermore, Geological Team 216 conducted considerable drilling work and estimated the uranium ore reserves in the Baiyanghe deposit [8]. These works showed that the Baiyanghe deposit has a high mineral potential and that the alteration is closely related to uranium mineralization.

The alteration of wall rock that is exposed at the surface of the Baiyanghe uranium deposit involves many different types of alteration, including hematitization, illite alteration, fluoritization, silicification, chloritization, and carbonatization during fieldwork and mapping at the surface of the Baiyanghe uranium deposit $[9,10]$. However, most of the above studies focused on only the ore-forming fluid characteristics, structural features and alteration characteristics of the Baiyanghe uranium deposit at the surface. Research on the alteration distribution, alteration environment and characteristics of the uranium ore-forming fluids at depth in the Baiyanghe deposit remains insufficient. Moreover, there is no deep understanding and study about the pressure and temperature (P-T) characteristics of the hydrothermal fluid in the Baiyanghe uranium deposit. Thus, we have conducted research on the hyperspectral remote-sensing alteration characteristics of drill cores from the Baiyanghe uranium deposit to examine the alteration characteristics of the Baiyanghe uranium deposit in three-dimensional space, to identify iconic alteration minerals that are associated with uranium ore formation and provide a reference for uranium exploration at depth, and we also have studied the pressure and temperature (P-T) characteristics of the hydrothermal fluid in the Baiyanghe uranium deposit using the pattern of the changes in the absorption-peak wavelength of illite at $2200 \mathrm{~nm}$ [11] and the SWIR-IC (short-wavelength infrared illite crystallinity, a dimensionless quantity) values, which are usually controlled by temperature and are useful for exploration [12].

A drill core is an effective record of deep geological information, and spectroscopic methods can be applied to drill cores to identify alteration minerals based on spectral data, map the distribution of alteration minerals, and evaluate the vertical spatial distribution of hydrothermal alteration. This type of research is a new direction for the acquisition and study of core-based geologic information [13-15]. Furthermore, spectroscopic methods have obvious and unique advantages in identifying sericite-group minerals (which differ in their aluminum contents), chlorite-group minerals (which differ in their aluminum, magnesium and iron contents) and argillaceous minerals, which are difficult to identify by visual inspection only [16]. In recent years, many Chinese and international researchers have successfully applied ground-based non-imaging portable hyperspectral instruments, such as PIMA (Portable Infrared Mineral Analyzer), ASD (produced by Analytical Spectral Devices (ASD) Inc.) and SVC HR1024, to log alteration information and perform field-based hyperspectral research on drill cores from various deposits. This work provides robust technical support for the exploration of deep mineral resources [17-20].

Based on these previous studies, we perform spectral measurements and analyses of nine drill cores from the Baiyanghe uranium deposit using a FieldSpec4 visible-shortwave infrared spectrometer. The hydrothermal alteration characteristics of the Baiyanghe deposit, the iconic alteration minerals that are associated with uranium ore formation, and the geologic characteristics (mainly the pressure and temperature characteristics of hydrothermal fluid) are discussed to establish a basis for deep exploration in the Baiyanghe uranium deposit.

\section{Geological Setting}

The Baiyanghe uranium deposit $\left(46^{\circ} 33^{\prime}-46^{\circ} 35^{\prime} \mathrm{N} ; 84^{\circ} 49^{\prime}-84^{\circ} 58^{\prime} \mathrm{E}\right)$ is located in the Xuemisitan (Xiemisitai) volcanic belt in western Junggar, Xinjiang [21]. The geological structure of this area is complex, with an extremely developed fault structure and multiple periods of tectonic and magmatic activity, which can be divided into three stages: (1) The early and middle Hercynian, which formed marine and continental volcanic rocks, exhibit a basic-neutral-acid evolution during the Devonian and marine-terrigenous volcanic rock debris during the Carboniferous. These rocks are connected 
with an unconformity. Moreover, an NE-trending compression and scissor fault, the Mengbulake Fault, and an E-W-trending compression deep fault, the Chagantaolegai-Bayinbulake Fault, formed during this period and contain many uranium areas, including the Baiyanghe deposit. (2) The late Hercynian is where the occurrence of large faults accompanied by multi-phase basic, neutral, acidic, and alkaline magmatic intrusions, when the granite porphyry of the Baiyanghe deposit formed. (3) The Yanshan-Himalayan period, which included tectonic activation following multiple thermal events, shows that the tectonic magmatic evolution in this area had undergone multi-cycle and multi-stage processes, resulting in many stages of uranium mineralization in the Baiyanghe deposit [22].

The Baiyanghe uranium deposit is an important deposit and has huge exploration prospects in the eastern Xuemisitan area, which also includes Xuemisitan, the Qiyi work area, the Shiyue work area, and the Mamente uranium mineralization area, all of which are located near the Chagantaolegai-Bayinbulake Fault (Figure 1). The areas near them feature many types of alteration, which are closely related to the uranium mineralization [6,21].

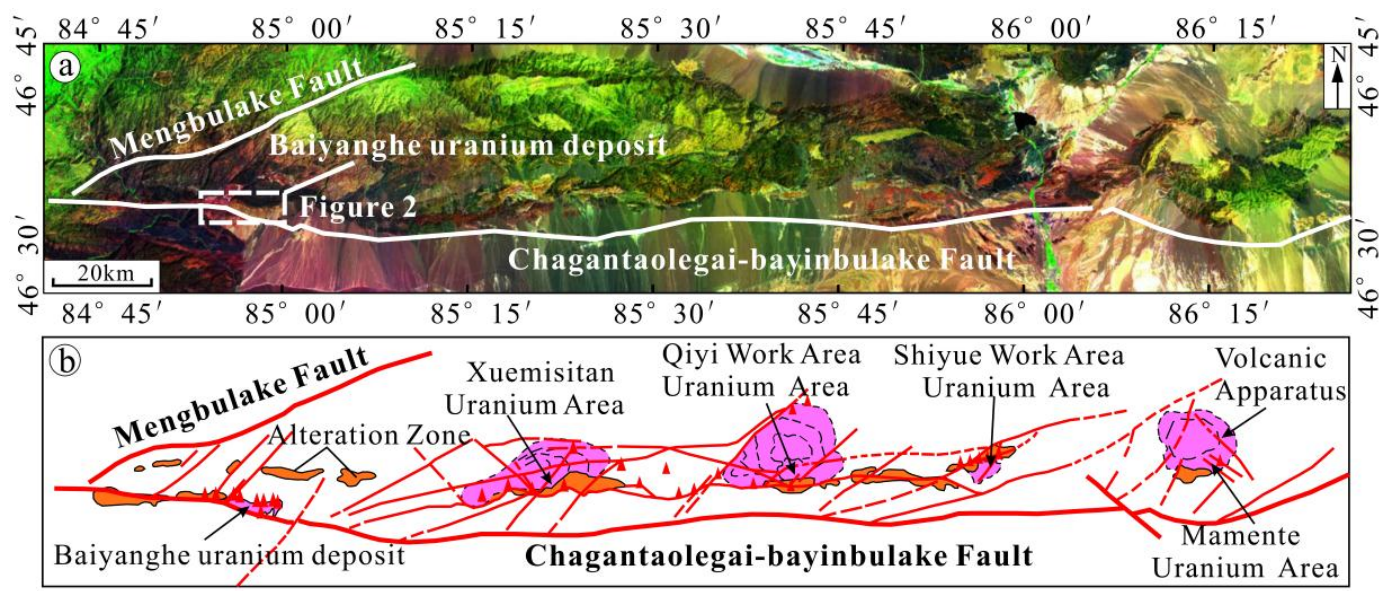

Figure 1. (a) LANDSAT 7 ETM+ pseudo-color image (Red: band 7, Green: band 4 and Blue: band 2) of the eastern Xuemisitan area and the Baiyanghe uranium deposit's location (image produced by stretching). The green areas represent vegetation, the mauve areas represent the Neogene sedimentary strata, and the black areas in the left of the image represent Carboniferous strata. (b) Interpreted image of the uranium ore volcanic deposit's distribution in the eastern Xuemisitan area (modified from [6,22]).

\subsection{Geology of the Baiyanghe Uranium Deposit}

The outcropping deposit strata include Devonian continental volcanic clastic rocks, Carboniferous marine sedimentary detrital rocks with andesitic porphyrite, basic volcanic rocks, intermediate-acid volcanic rocks, and volcaniclastic rocks that are characterized as marine facies and marine-continental interactive facies. Additionally, Permian granite porphyry and tuffaceous sandstone are present [22]. The granite porphyry in the Baiyanghe deposit contains a large number of diabase and diorite veins that formed at $309 \mathrm{Ma}$. The intrusion of the intermediate-basic dikes occurred after the formation of the granite porphyry, and previous studies suggested that the metallogenic age of the asphaltic uranium deposit is similar to the intrusion age of the diabase veins [23].

The spatial distribution of the uranium deposit is controlled by fractures in the ChagantaolegaiBayinbulake unit, which consists of the Yangzhuang rock body, Asuda rock body, and small Baiyanghe rock body, and both drill profiles are located within the Yangzhuang rock body (Granite Porphyry body) (Figure 2). The geologic structure of the area is complicated, and numerous faults crosscut the region. The folded structure is clearly expressed only in the western areas and is disrupted by faults and intrusive rocks. The ore-controlling structure of the Baiyanghe deposit consists of contact-zone structures and fault structures. Both structures have consistent spatial distributions, and the contact-zone structure primarily developed in and around the main fault [24] (Figure 2). 


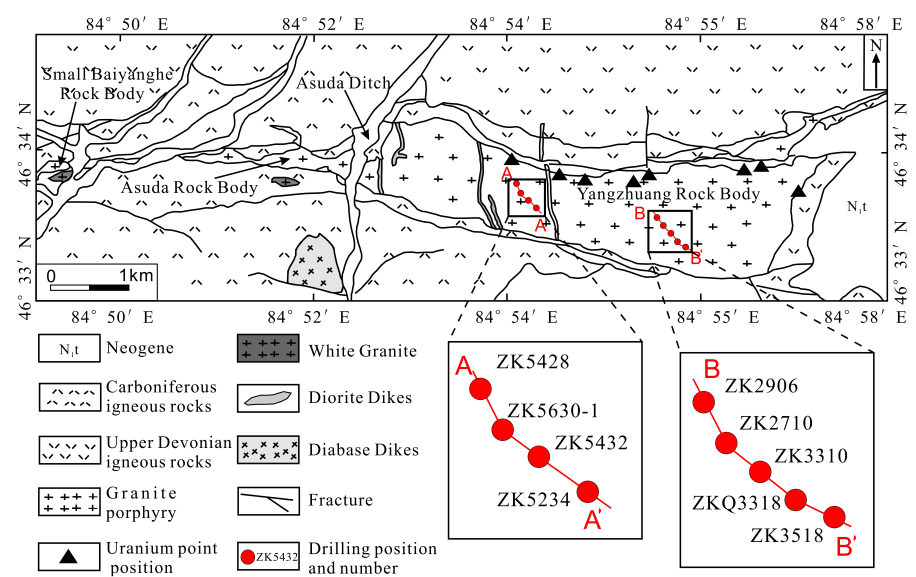

Figure 2. Geological map of the Baiyanghe uranium deposit and drilling locations (modified from [22,24]).

\subsection{Uranium Mineralization of the Baiyanghe Deposit}

The first uranium mineralization that was discovered is located near the northern rim contact zone of the eastern section of the Yangzhuang rock body and is relatively low grade [22]. In contrast, the uranium mineralization that was discovered in recent years is mainly located in the central intrusive body of the central and western sections of the Yangzhuang rock body and is relatively high grade in the horizontal direction. Two trends are evident in the planar distribution of the uranium mineralization: one group of ore bodies trends E-W along the northern rim of the ore area, and the other trends NW-SE in the center of the ore area (Figure 3a) [24]. Vertically, the ore bodies occur in the Upper Carboniferous microcrystalline granite porphyry near the contact zone with the acid volcanic rocks of the Upper Devonian Taerbarhata Formation [3] (Figure 3b).

The U-Pb isotopic ages of asphalt uranium ore in the Baiyanghe deposit can be divided into four stages, $224 \pm 3.1$ to $237 \pm 3.3 \mathrm{Ma}, 197.8 \pm 2.8 \mathrm{Ma}, 97.8 \pm 1.4 \mathrm{Ma}$, and $30 \pm 0.4 \mathrm{Ma}$, which are later than the intrusion time of the granite porphyry, indicating the post-magmatic and multi-stage mineralization of pitchblende [25]. Studies suggested that the Baiyanghe uranium-beryllium deposit belongs to the same type of deposit as the Spokane Mountain beryllium-uranium hydrothermal deposit in the United States. Additionally, the beryllium-uranium mineralization of the Baiyanghe deposit occurred during the hydrothermal stage after the diagenetic stage $[23,26]$.

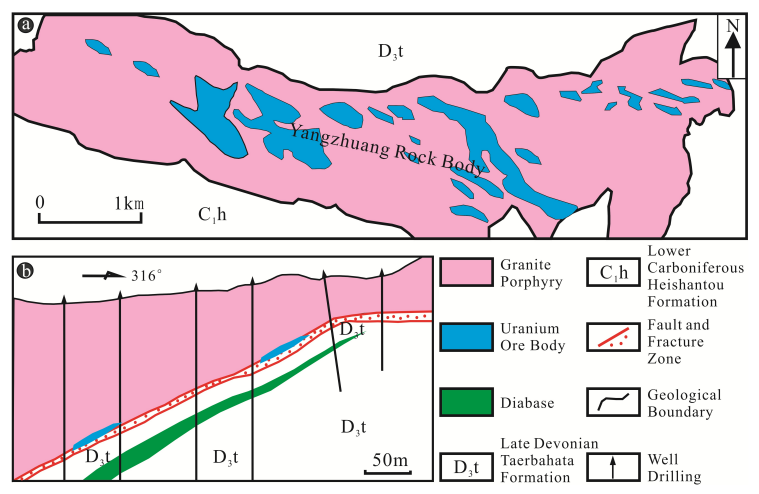

Figure 3. (a) Planar distribution of the uranium ore body in the Baiyanghe Uranium deposit. (b) Uranium ore body's position in a geological cross section (modified after $[3,24]$ and Geological Team 216).

\subsection{Wall-Rock Alteration of the Baiyanghe Deposit}

The wall rocks in the Baiyanghe uranium deposit feature many types of alteration, including hematitization, illite alteration, fluoritization, silicification, chloritization, and carbonatization [9]. 
The alteration zones' locations and styles, and the alteration minerals in each of the alteration zones are shown in Table 1. Hematite and illite alteration occurs near the contact zone between the Yangzhuang rock body and the peripheral volcanic rocks and exhibits distinct zoning characteristics. Additionally, a significant spatial correlation exists between the uranium occurrences and the hematitization and illite alteration [6].

Table 1. Wall-rock alteration locations, styles and alteration minerals.

\begin{tabular}{ccc}
\hline Alteration Zones & Alteration Styles & Alteration Minerals \\
\hline \multirow{3}{*}{ Northern alteration zone } & Ferric Iron alteration & Hematite Limonite \\
& Illite alteration & Illite \\
& Fluoritization & Fluorite \\
& Chloritization & Chlorite \\
\hline \multirow{2}{*}{ Southern alteration zone } & Illite alteration & Illite \\
& Carbonatization & Carbonate \\
\hline \multirow{3}{*}{ Western and Eastern alteration zones } & Illite alteration & Illite \\
& Chloritization & Chlorite \\
& Carbonatization & Carbonate \\
& Fluoritization & Fluorite \\
\hline \multirow{2}{*}{ Rock body alteration zone } & Ferric Iron alteration & Hematite Limonite \\
& Silicification & \\
& Carbonatization & Carbonate \\
\hline
\end{tabular}

\section{Methodology}

\subsection{Working Method}

The hyperspectral instrument used in this study was a FieldSpec4 visible-shortwave infrared spectrometer, which was produced in the United States. This instrument's spectral range is $350-2500 \mathrm{~nm}$, and its spectral resolution is $3 \mathrm{~nm}$ in the range of $350-1050 \mathrm{~nm}$ and $10 \mathrm{~nm}$ in the range of 1050-2500 nm. This instrument can be used to identify hydroxyl-containing silicate, sulfate, and carbonate minerals and detect hematitization and ferritization [27].

After the data were obtained, the ViewSpecpro software was used to convert the spectral reflectance curve data into a .txt file. Then, we used the Spectral Analyst of ENVI 4.8 to analyze quantitatively spectra with the reference spectral library of the United States Geological Survey (USGS), and the ENVI 4.8 software platform was used to transform the spectral curve data into a spectral library. Finally, the spectral characteristics and mineral identification of every curve were individually analyzed using the spectral library of the United States Geological Survey (USGS) via visual interpretation analysis data to more accurately confirm minerals once again, and to examine these spectra after Spectral Analyst of ENVI $[7,28]$, according to the data processing workflow in Figure 4.

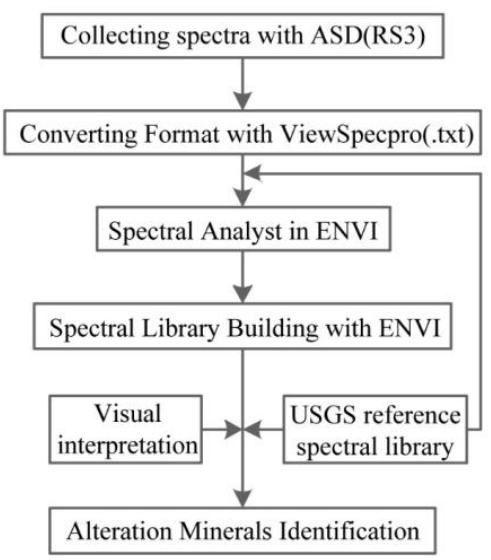

Figure 4. Processing workflow to analyze the drill core's hyperspectral data. 
The spectral characteristics were analyzed in terms of the form of each spectral curve, the wavelength location of the main absorption peak, and the combination features of the absorption peak. Mineral identification was based on the principle that a specific alteration mineral exhibits specific spectrum-absorption characteristics in the visible-shortwave infrared band. The type of mineral in each measured curve was determined by comparing the measured spectra and typical mineral examples in the USGS spectral library.

\subsection{Hyperspectral Data Collection from the Drill Cores}

This study conducted contact measurements of the ground spectra and spectral characteristics of nine drill cores from the Baiyanghe uranium deposit and measured the $U_{\gamma}$ values of the nine drill cores. First, we wiped the drill cores with dry rags, and then we conducted contact measurements of the spectra using the ASD High Brite Contact Probe to eliminate the effects of water vapor in the air. In particular, the ASD High Brite Contact Probe must be wiped clearly so as not to affect the measurements of other altered minerals when the alteration of the drill cores changes. The spectral measurements were collected in contact mode using a built-in light source. The dot pitch of the spectral measurement was approximately $30 \mathrm{~cm}$, and closely spaced measurements were performed in the strongly altered sections, which were approximately $10 \mathrm{~cm}$ in length. Two curves were recorded for each measurement point.

The distribution of the eight drill holes is shown in Figure 2: ZK5432, ZK5630-1, ZK5234, and ZK5428 in the central and western ore area; and ZK3310, ZK2710, ZKQ3318, ZK2906 and ZK3518 in the eastern ore area. In total, 14,876 spectra were collected. The uranium mineralization in the central and western ore areas is better than that in the eastern area according to the $U_{\gamma}$ values and geological data of the Geological Team $216[21,23]$. The number of spectra was very large, so we selected a small portion of the spectra data from the drill hole ZK5630-1 in Table 2.

Table 2. Spectra and $U_{\gamma}$ values of the drill hole ZK5630-1.

\begin{tabular}{|c|c|c|c|}
\hline Depth $(\mathrm{m}) *$ & Spectral Number ** & $\mathrm{U}_{\gamma}$ Value (ppm) & Identified Mineral \\
\hline \multirow[t]{2}{*}{310.00} & $1265-1266$ & 54.10 & Limonite \\
\hline & 1295-1296 & & Limonite \\
\hline \multirow[t]{3}{*}{322.00} & $1321-1324$ & & Illite \\
\hline & $1323-1324$ & 206.09 & Illite \\
\hline & $1325-1326$ & & Illite \\
\hline \multirow{4}{*}{323.67} & $1327-1328$ & & Illite \\
\hline & 1329-1330 & 489.44 & Illite \\
\hline & 1331-1332 & & Illite \\
\hline & 1339-1340 & & Illite, Hematite \\
\hline \multirow[t]{4}{*}{324.00} & 1341-1342 & 1817.27 & Illite \\
\hline & $1349-1350$ & & Hematite \\
\hline & $1353-1354$ & & Hematite \\
\hline & $1355-1356$ & 1173.04 & Hematite \\
\hline \multirow[t]{4}{*}{326.00} & $1357-1358$ & & Illite \\
\hline & 1359-1360 & & Illite, Hematite \\
\hline & $1363-1364$ & 2175.50 & Hematite \\
\hline & 1369-1370 & & Hematite \\
\hline \multirow[t]{5}{*}{328.00} & 1373-1374 & & Hematite \\
\hline & $1377-1378$ & & Limonite \\
\hline & 1381-1382 & 771.96 & Limonite \\
\hline & $1387-1388$ & & Hematite \\
\hline & 1393-1394 & & Hematite \\
\hline \multirow[t]{4}{*}{332.00} & 1401-1402 & & Hematite \\
\hline & 1403-1404 & & Hematite \\
\hline & $1427-1428$ & 78.71 & Hematite \\
\hline & $1429-1430$ & & Illite \\
\hline 335.00 & 1431-1432 & & Illite \\
\hline
\end{tabular}

* The depth of 310.00-335.00 $\mathrm{m}$ is the uranium mineralization section of the drill hole ZK5630-1, and the $\mathrm{U}_{\gamma}$ values are high. ${ }^{* *}$ The number of spectra covers only a small section of the drill hole; the amount of data was large, so we selected these spectra. 
The uranium ore body was observed via four drill holes in the central and western sections of the deposit. This body is located between the north-south diabase and diorite veins and contains a number of thin diabase veins. Four drill holes-ZK5432, ZK5630-1, ZK5234, and ZK5428-are located in the middle or on the edge of the relatively high-quality uranium ore body that was recently discovered, and ZK5432 and ZK5630-1 are industrial holes with good mineralization. The uranium content in the drill cores reached $9319 \times 10^{-6} \mathrm{ppm}$. ZK5428 is an abnormal hole, and ZK5234 is a hole with a relatively small amount of alteration minerals. Visible diabase veins were less apparent at the surface of the four drill holes at the eastern end of the deposit. The eastern uranium ore body is smaller than that in the central and western areas. Five drill holes-ZK3310, ZK2710, ZKQ3318, ZK2906 and ZK3518 - are distributed in the middle or on the edge of various small mineralized bodies or uranium anomaly areas. According to the actual measurements, ZK3310 is an abnormal hole, whereas ZK2710, ZKQ3318, ZK2906 and ZK3518 are drill holes with relatively small amounts of alteration minerals.

\subsection{Identification of Alteration Minerals}

Illite is the most common mineral identified in the hyperspectral mapping results. Illite has an absorption peak at approximately $2200 \mathrm{~nm}$, and its intensity is negatively correlated with the $\mathrm{Al}^{\mathrm{VI}}$ content [27]. Previous studies divided illite into short-wavelength illite and long-wavelength illite (i.e., Al-rich illite and Al-poor illite) according to the positions changes of the absorption-peak wavelength of illite at $2200 \mathrm{~nm}$, but the specific division standards that distinguish different geological conditions slightly differ $[29,30]$.

When identifying white mica (illite and muscovite) minerals with hyperspectral technology, the division into two or three types strongly depends on the spectral resolution of the spectrograph and the maximum and minimum values of the spectral absorption-peak wavelength of the white mica (illite and muscovite) minerals at $2200 \mathrm{~nm}$ in that specific area. Therefore, geological analysis and prospecting that involves identifying short-wavelength white mica (illite and muscovite), medium-wavelength white mica (illite and muscovite), and long-wavelength white mica (illite and muscovite) begins with characterizing the specific conditions of the studied area.

The statistical results indicated that the appropriate boundaries of the Baiyanghe area are $2203 \mathrm{~nm}$ between short-wavelength illite and medium-wavelength illite and $2213 \mathrm{~nm}$ between medium-wavelength illite and long-wavelength illite. The spectral curves of illite, chlorite, hematite, limonite (mixture of Goethite and Lepidocrocite, but mainly goethite), carbonate, and montmorillonite are shown in Figure 5.

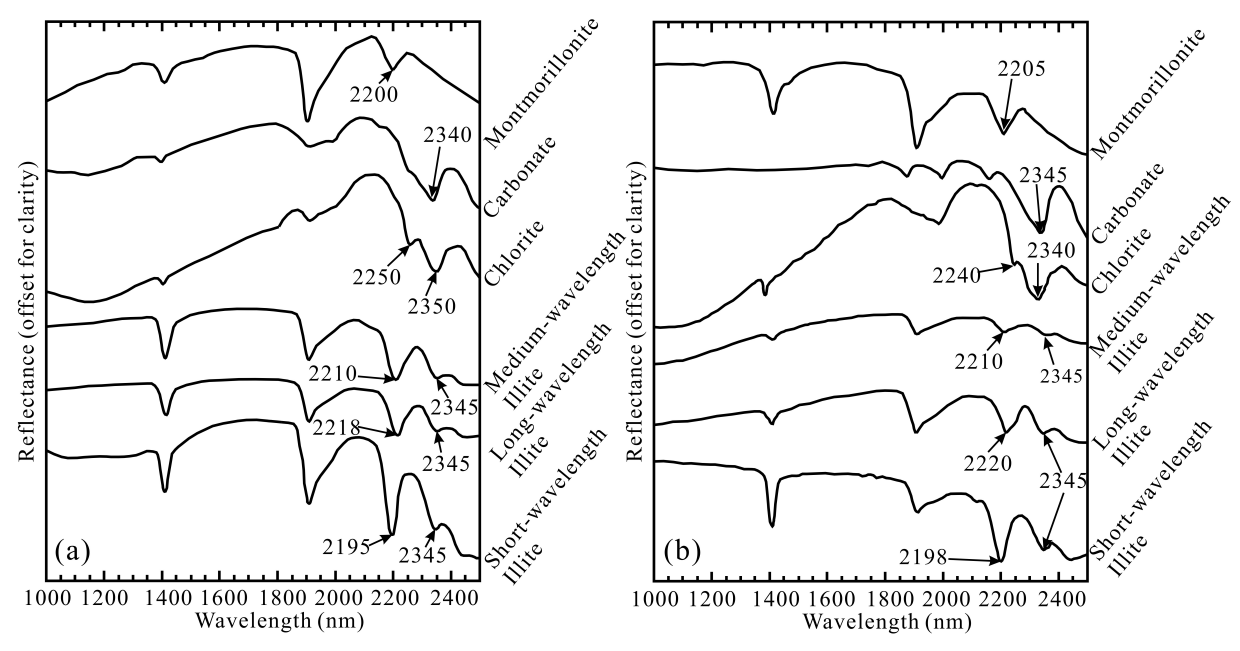

Figure 5. Cont. 

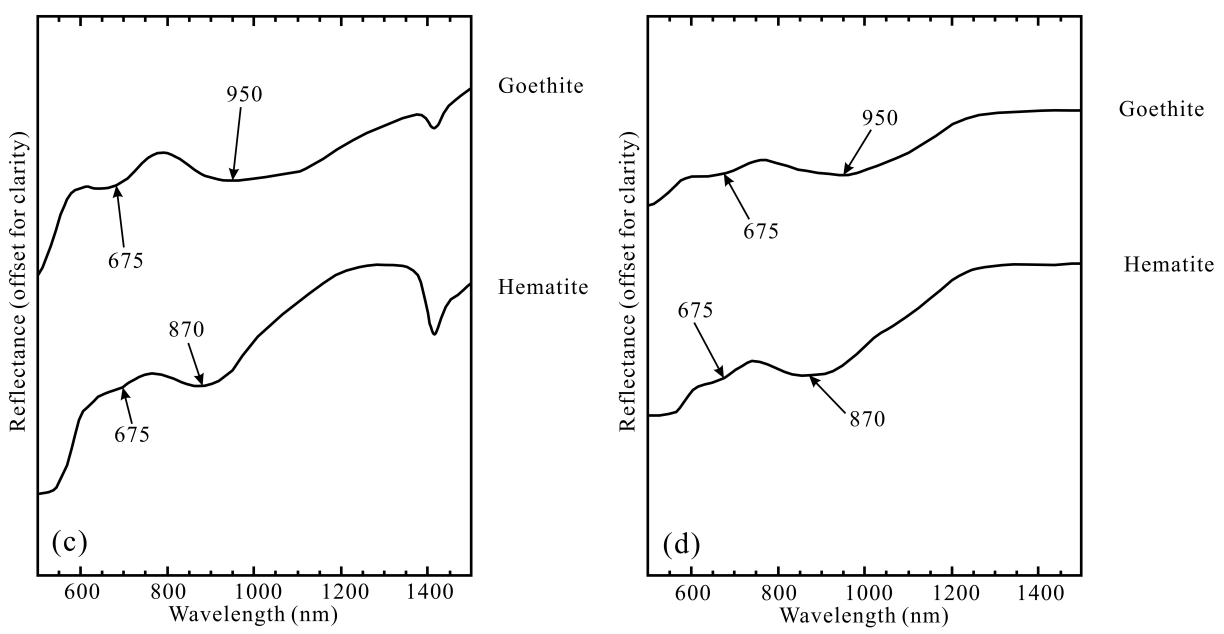

Figure 5. (a-d) Spectral curves of the investigated alteration minerals (500-2500 nm): (a,c) spectral curves of the alteration minerals measured from the drill cores of the Baiyanghe uranium deposit; and (b,d) spectral curves from the reference spectral library of the United States Geological Survey (USGS).

In the Yangzhuang sub-volcanic rock body (granite porphyry) in the Baiyanghe deposit and the internal and external contact zones of the underlying tuffaceous sandstone body, eight types of simple alteration minerals-hematite, limonite (it is a mixture of Goethite and Lepidocrocite, but mainly goethite), short-wavelength illite, medium-wavelength illite, long-wavelength illite, carbonate, chlorite, and montmorillonite-were identified, alongside some mixed minerals with a variety of minerals combinations. The curves of these eight types of simple alteration minerals are shown in Figure 6.
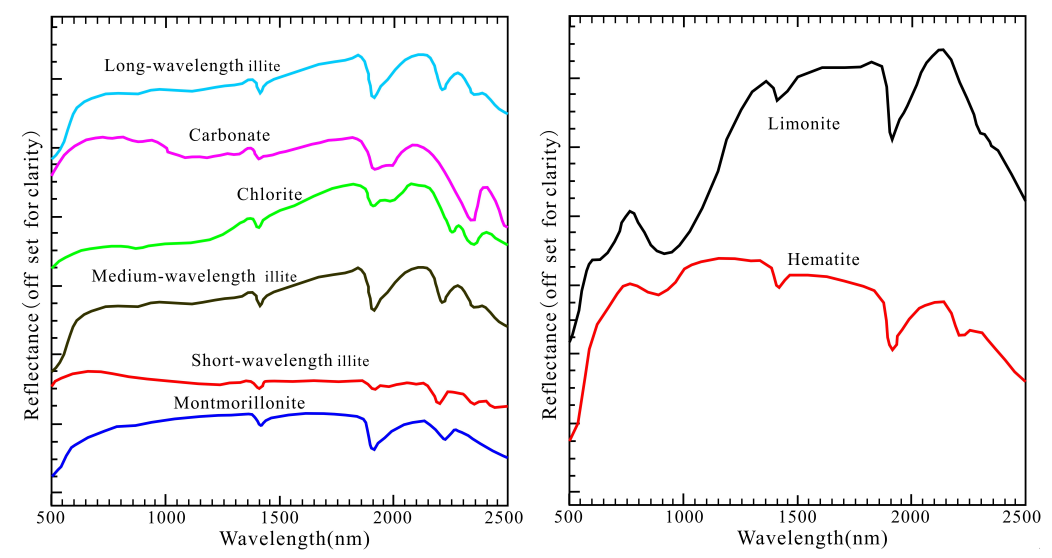

Figure 6. Spectral curves (500-2500 nm) of the eight investigated alteration minerals.

The spectral characteristics of short-wavelength illite, medium-wavelength illite, long-wavelength illite, and the other five types of alteration minerals are summarized in Table 3.

Table 3. Absorption features of the eight investigated alteration minerals.

\begin{tabular}{cc}
\hline Alteration Minerals & Characteristic Absorption-Peak Location (s) \\
\hline Short-wavelength illite & $2195-2202 \mathrm{~nm}, 2345 \pm 5 \mathrm{~nm}$ \\
Medium-wavelength illite & $2203-2212 \mathrm{~nm}, 2345 \pm 5 \mathrm{~nm}$ \\
Long-wavelength illite & $2213-2220 \mathrm{~nm}, 2345 \pm 5 \mathrm{~nm}$ \\
Montmorillonite & $2200 \mathrm{~nm} \pm 5 \mathrm{~nm}$ \\
Chlorite & $2250-2260 \mathrm{~nm}, 2340-2350 \mathrm{~nm}$ \\
Carbonate & $2320-2340 \mathrm{~nm}$ \\
Hematite & $675 \pm 5 \mathrm{~nm}, 870 \mathrm{~nm} \pm 5 \mathrm{~nm}$ \\
Limonite & $675 \pm 5 \mathrm{~nm}, 950 \mathrm{~nm} \pm 5 \mathrm{~nm}$ \\
\hline
\end{tabular}




\section{Results}

Vertical alteration mineral catalogs and analyses were developed for all nine drill holes through statistical analysis and mineral identification. We found that illite was identified as the most common alteration mineral in most of the drill cores from the nine drill holes, and other alteration minerals are also relatively developed and exhibit local distributions in the drill holes.

\subsection{Geological Characteristics of Drill Hole ZK5630-1}

Drill hole ZK5630-1 is $390.13 \mathrm{~m}$ deep and is a good industrial hole. The strata from the surface to the bottom of the hole are as follows: (1) The Neogene system primarily consists of residual slope deposits of granite porphyry and clay. (2) The intrusive rock is mainly Permian hypabyssal intrusive granite porphyry. Quartz and feldspar crystals are unevenly distributed throughout the rock, exhibit relatively high variability, and are locally fragmented by joints and fractures. The rock body is relatively intact, but some portions are fragmented, and joints and fractures are relatively well developed. The alteration processes in the contact zone include hematitization, chloritization, fluoritization, illite alteration and carbonatization. (3) The Upper Devonian Taerbarhata Formation is fragmented in certain locations and exhibits carbonation, chloritization, and ferritization. The structure in the drill hole is characterized by extensional secondary fractures. A structural fracture belt is present at a depth of 335-342 $\mathrm{m}$ and is filled with tuffaceous sandstone breccia and structural clay.

The uranium mineralization section occurs at depths between 310 and $336.6 \mathrm{~m}$ in drill hole ZK5630-1 and has a thickness of $26.6 \mathrm{~m}$. This section is located in the rock body around the contact zone and in the volcanic rock strata and contains macroscopic fluorite, secondary uranium minerals, and hematite. Secondary uranium minerals are well developed in the joint fissures of the mineralization section and are yellow. Furthermore, secondary uranium minerals and hematite locally coexist. Fluorite, hematite, and some secondary uranium minerals locally developed along the fracture surface, forming mixed alteration patterns.

Gamma-ray intensity measurements of drill hole ZK5630-1 were performed in the field using a HD-2000 gamma indicator, revealing a U content below 10 ppm at depths between 0 and $90 \mathrm{~m}$ depth. The U content from 90 to $150 \mathrm{~m}$ fluctuates within 10-25 ppm, whereas the U content between 150 and $300 \mathrm{~m}$ is lower than $10 \mathrm{ppm}$. The $\mathrm{U}$ content from 300 to $350 \mathrm{~m}$ increases from $10 \mathrm{ppm}$ to a maximum of $2175 \mathrm{ppm}$ and then decreases to $10 \mathrm{ppm}$. The mineralization section of the drill hole is located between 308 and $335 \mathrm{~m}$, and the $U$ content in this area is high. At depths below $350 \mathrm{~m}$, however, the $U$ value is relatively low (i.e., below $10 \mathrm{ppm}$ ).

\subsection{Alteration Zoning Characteristics of Drill Hole ZK5630-1}

From 0 to $210 \mathrm{~m}$ depth, the alteration minerals in drill hole ZK5630-1 include long-wavelength illite and relatively smaller amounts of montmorillonite, hematite and limonite, and the characteristic absorption wavelength of the long-wavelength illite is 2213-2220 nm. Between 210 and $300 \mathrm{~m}$, the alteration minerals include medium-wavelength illite, long-wavelength illite, and smaller amounts of montmorillonite. The wavelength of the medium-wavelength illite is 2203-2212 nm, whereas that of the long-wavelength illite exceeds 2213 nm. From 300 to $340 \mathrm{~m}$, many types of alteration minerals are present, including short-wavelength illite, medium-wavelength illite, chlorite, and hematite, which are well developed, alongside smaller amounts of long-wavelength illite and carbonate. The mineralization section is located between 308 and $335 \mathrm{~m}$. From 340 to $390.13 \mathrm{~m}$, the alteration minerals include chlorite, short-wavelength illite and carbonate. The mixture of chlorite and short-wavelength illite in this section is relatively complicated, and the characteristic absorption-peak wavelength range is between 2195 and $2202 \mathrm{~nm}$. Performing a statistical analysis of the types of alteration minerals, changes in $\mathrm{U}$ content (ppm), alteration intensity (the number of identified alteration minerals), and the absorption-peak wavelength of illite at $2200 \mathrm{~nm}$ enabled us to create a comprehensive informative map of the hyperspectrally identified alteration minerals in the drill cores, as shown in Figure 7. 


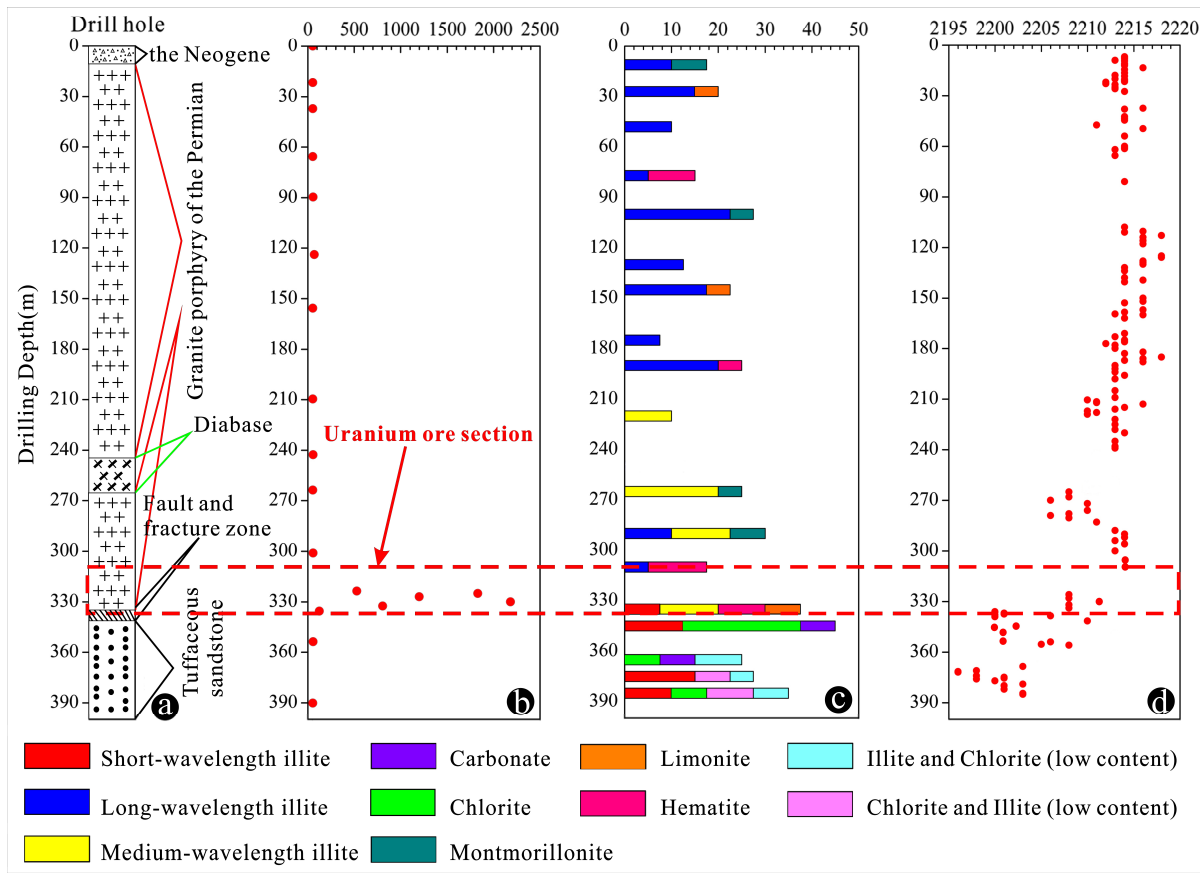

Figure 7. (a) Geological sketch map of drill hole ZK5630-1 (the numbers on the left are the depths of the drill hole). (b) Map of the measured U content (ppm) in the drill core (the numbers at the top are the $U_{\gamma}$ values, and the numbers on the left are the depths of the drill hole). (c) Vertical distribution log of the alteration minerals in the drill core and the variations in their intensities (the numbers at the top are the number of identified alteration minerals) with depth. In the same histogram, the variations in the types of alteration minerals with depth and the intensity of the alteration are indicated by the intensity of the color. (d) Chart of the absorption-peak wavelength (1000-2500 nm) of illite at $2200 \mathrm{~nm}$ (the numbers at the top are absorption-peak wavelength of illite at $2200 \mathrm{~nm}$, and the numbers on the left are the depths of the drill hole).

According to the above description and analysis (Figure 7), the alteration minerals in drill core ZK5630-1 can be divided into different sections. From 0 to $210 \mathrm{~m}$ depth, the alteration mineral assemblage includes long-wavelength illite, minor hematite, minor limonite and minor montmorillonite. Between 210 and $340 \mathrm{~m}$, the alteration mineral assemblage consists of the three types of illite (long-, medium- and short-wavelength), chlorite, hematite, and minor carbonate. At depths below $340 \mathrm{~m}$, the alteration mineral assemblage comprises short-wavelength illite, chlorite, and minor carbonate. The uranium mineralization anomaly is located at a depth of approximately $308-335 \mathrm{~m}$, and an assemblage of short- and long-wavelength illite, chlorite, and hematite is present at this depth. From the surface to the bottom, the general trend of the absorption-peak wavelength of illite at $2200 \mathrm{~nm}$ throughout the hole initially decreases gradually and then increases. Additionally, this trend crosses the boundary between the upper granite porphyry and the underlying tuffaceous sandstone body (near $340 \mathrm{~m}$ ). In other words, there is a shift on the absorption-peak wavelength (1000-2500 nm) of illite at $2200 \mathrm{~nm}$ towards shorter wavelength from approximately $2215 \mathrm{~nm}$ to $2195 \mathrm{~nm}$ between 0 and $370 \mathrm{~m}$, whereas there is a shift of the minimum absorption towards longer wavelength slightly from $2195 \mathrm{~nm}$ to approximately $2203 \mathrm{~nm}$ between 360 and $390 \mathrm{~m}$.

\subsection{Alteration Zoning Characteristics of the Cross Sections}

Drill hole ZK5432 is located approximately 100 or 120 m southeast of ZK5630-1 and has a depth of $390 \mathrm{~m}$. This drill hole is also a good industrial hole. From the surface to the bottom of the hole, the lithology changes from granite porphyry to tuffaceous sandstone body. A fracture zone with a thickness of approximately 8-10 m exists in the contact area between the two different rock bodies. 
The main mineralization section is located at a depth of $330-345 \mathrm{~m}$, and the uranium content in this section increases from $20 \mathrm{ppm}$ to $9319 \mathrm{ppm}$.

From 0 to $190 \mathrm{~m}$ depth, the alteration minerals in drill hole ZK5432 include long-wavelength illite and comparatively minor montmorillonite, hematite and limonite. From 190 to $320 \mathrm{~m}$, the alteration minerals comprise medium-wavelength illite, long-wavelength illite, and minor montmorillonite. Between 320 and $360 \mathrm{~m}$ depth, many varieties of alteration minerals are present, including short-wavelength illite, medium-wavelength illite, chlorite, and hematite, which are abundant, alongside long-wavelength illite and carbonate, which are relatively less abundant. From $360 \mathrm{~m}$ to the bottom of the section, the alteration minerals include chlorite and short-wavelength illite, and the mixture of chlorite and short-wavelength illite in this section is relatively complicated. Additionally, the short-wavelength illite gradually decreases and eventually disappears, whereas the chlorite gradually increases. The position of the absorption-peak wavelength of the alteration illite at $2200 \mathrm{~nm}$ exhibits a decreasing trend from the surface to the deeper sections of the drill core and crosses the boundary (near $370 \mathrm{~m}$ ) between the upper granitic porphyry and the underlying volcanic rocks. The absorption-peak wavelength of illite at $2200 \mathrm{~nm}$ is higher than $2213 \mathrm{~nm}$ between 0 and $190 \mathrm{~m}$ depth and is typically 2213-2218 nm. Between 190 and $325 \mathrm{~m}$ depth, the absorption-peak wavelength of illite at $2200 \mathrm{~nm}$ is between $2203 \mathrm{~nm}$ and $2213 \mathrm{~nm}$, and the distribution of the peak is relatively uniform. However, the absorption-peak wavelength of illite at $2200 \mathrm{~nm}$ decreases from $2213 \mathrm{~nm}$ to $2196 \mathrm{~nm}$ as the depth increases from 325 to $398 \mathrm{~m}$. These features show that the alteration mineral assemblage in ZK5432 and the variations in the spectral absorption-peak wavelength of illite at $2200 \mathrm{~nm}$ are similar to those in drill ZK5630-1, as described above.

Drill hole ZK5428 is $319.12 \mathrm{~m}$ deep and is located approximately $100 \mathrm{~m}$ from drill holes ZK5432 and ZK5630-1. The uranium anomaly section is located at a depth of approximately $246-255 \mathrm{~m}$, and the black diabase vein is located at a depth of 116-176 $\mathrm{m}$, which does not respond spectrally [31]. Mineralization was not discovered in ZK5234, but the alteration was relatively well developed. Drill hole ZK5234 is located approximately $300 \mathrm{~m}$ southeast of ZK5432, reaches a depth of $400.35 \mathrm{~m}$, and has relatively low uranium content. The alteration mineral assemblages in drill holes ZK5428 and ZK5234 and the variations in the spectral absorption-peak wavelength of illite at $2200 \mathrm{~nm}$ are similar to those of the two above holes. Drill holes ZK3310, ZK2710, ZKQ3318, ZK2906 and ZK3518 are located at the eastern end of the ore district and exhibit very weak mineralization. Their alteration mineral assemblages and variations in the spectral absorption-peak positions of illite at $2200 \mathrm{~nm}$ are similar to those of the four above drill holes.

Based on the summary of the vertical variations in the alteration mineral assemblages and the variations in the spectral absorption-peak wavelength of illite at $2200 \mathrm{~nm}$, the vertical distribution of the alteration mineral assemblages in the nine drill holes ZK5432, ZK5630-1, ZK5234, ZK5428, ZK3310, ZK2710, ZKQ3318, ZK2906 and ZK3518 can be divided into three zones, namely, an upper section, a middle section and a lower section, which contain different alteration mineral assemblages. If viewed only in terms of illite alteration, these three zones can be further simplified into an upper long-wavelength illite section, a lower short-wavelength illite section, and a middle transition zone with all three types of illite (long-, medium- and short-wavelength) (Figure 8). However, the boundaries and thicknesses of these belts differ among the drill holes.

Cross sections ( $\mathrm{AA}^{\prime}$ and $\mathrm{BB}^{\prime}$ in Figure 2) of the alteration can be drawn according to the above description and the geologic background of the Baiyanghe deposit. These cross sections clearly show the zoning characteristics in the nine drill holes (Figure 9a,b). Furthermore, we can discuss the alteration zonation of the deposit, which should be similar to the cross sections $\mathrm{AA}^{\prime}$ and $\mathrm{BB}^{\prime}$, based on previous research results and geological profiles. In other words, the Baiyanghe uranium deposit contains three zones: (1) an upper section, which comprises long-wavelength illite and minor hematite and montmorillonite; (2) a middle section, which contains three types of illite (long-, mediumand short-wavelength) and hematite; and (3) a lower section, which includes short-wavelength illite, chlorite, illite-chlorite mixtures, and carbonate (Figure 9c,d). 

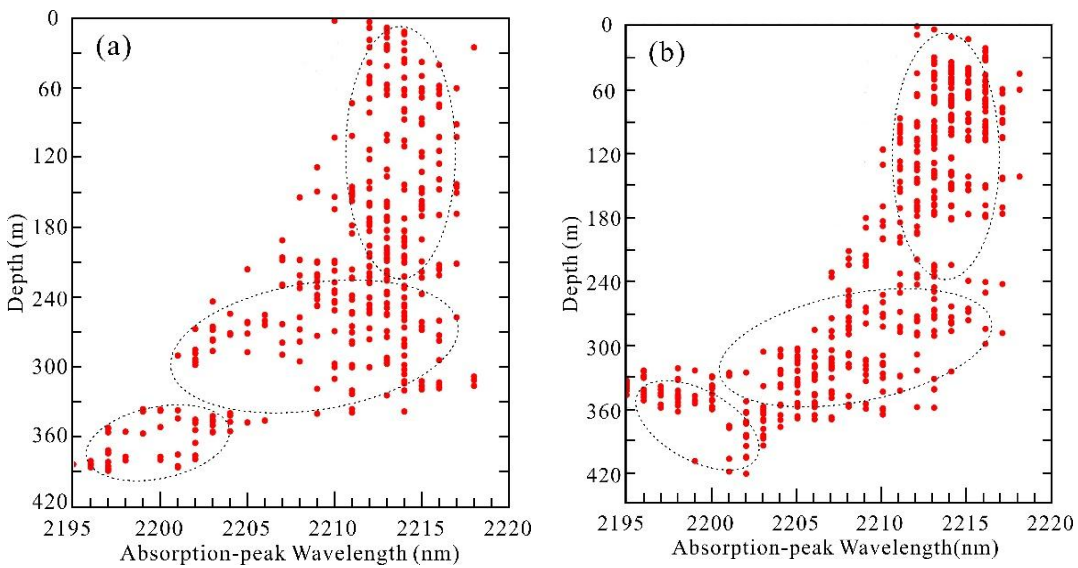

Figure 8. (a) Changes in the absorption-peak wavelength (1000-2500 nm) of illite at $2200 \mathrm{~nm}$ in drill holes ZK5432, ZK5630-1, ZK5234 and ZK5428. (b) Changes in the absorption-peak wavelength (1000-2500 nm) of illite at 2200nm in drill holes ZK3310, ZK2710, ZKQ3318, ZK3518 and ZK2906.

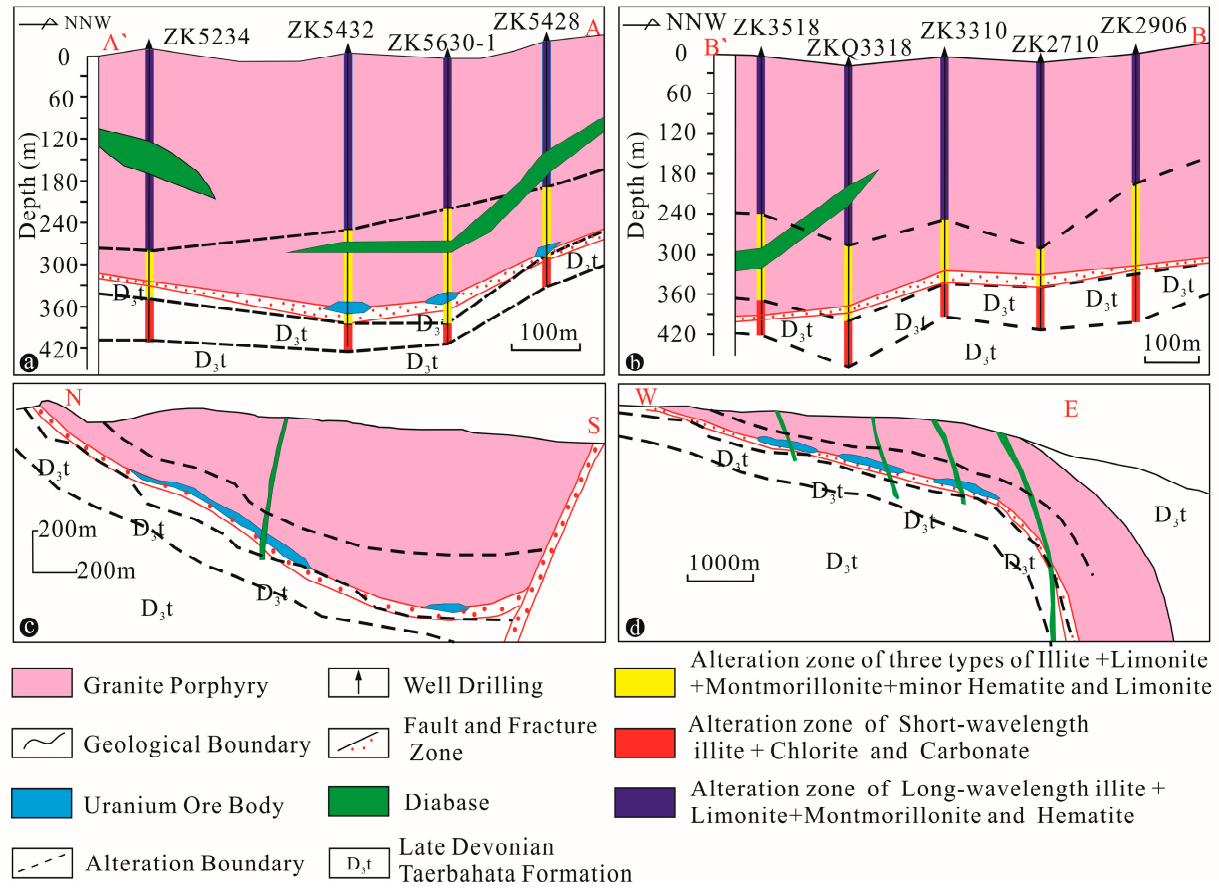

Figure 9. (a) Alteration zoning in cross section $\mathrm{AA}^{\prime}$. (b) Alteration zoning in cross section BB'. (c) Inferred alteration zoning of the cross sections in the N-S direction (modified from the Geological Team 216). (d) Inferred alteration zoning of the cross sections in the E-W direction (modified from the Geological Team 216).

\subsection{SWIR-IC Analysis of the Drill Holes}

Short-wavelength infrared (1000-2500 nm) illite crystallinity (SWIR-IC) is an important spectral parameter for the sericite group. It is usually controlled by the temperature and is useful for exploration [18,19]. SWIR-IC studies are based on short-wavelength infrared (SWIR) spectral features, and the SWIR-IC is defined as the absorption-peak depth of illite at $2200 \mathrm{~nm}$ divided by the absorption-peak depth of illite at $1900 \mathrm{~nm}$ on a hull quotient SWIR spectrum [18].

The SWIR-IC value can be computed using Equation (1), where Dep2200 is the absorption-peak depth of illite at $2200 \mathrm{~nm}$ and Dep1900 is the absorption-peak depth of illite at $1900 \mathrm{~nm}$. This study conducted contact measurements of the ground spectrum and spectral characteristics of nine drill 
cores from the Baiyanghe uranium deposit using the ASD High Brite Contact Probe to eliminate the effects of water vapor in the air. We wrote a program in MATLAB 8.1 to compute SWIR-IC.

$$
\text { SWIR }- \text { IC }=\frac{\text { Dep2200 }}{\text { Dep1900 }}
$$

In drill holes ZK5630-1, ZK5432 and ZK2710, the absorption peak of illite at $1900 \mathrm{~nm}$ ranges between $1901 \mathrm{~nm}$ and $1915 \mathrm{~nm}$ but is primarily between $1907 \mathrm{~nm}$ and $1912 \mathrm{~nm}$. The absorption peak of illite at $2200 \mathrm{~nm}$ ranges between $2195 \mathrm{~nm}$ and $2220 \mathrm{~nm}$ but is primarily between $2197 \mathrm{~nm}$ and 2204 $\mathrm{nm}$ and between $2208 \mathrm{~nm}$ and $2216 \mathrm{~nm}$ (Figure 10a'- $\mathrm{c}^{\prime}$ ). The SWIR-IC ranges between 0.2 and 2.1 but is mainly between 0.4 and 0.8 and between 1.1 and 1.6. Differences in the absorption peak of illite at $2200 \mathrm{~nm}$ and the SWIR-IC are obvious in the vertical direction in the three drill holes: (1) in the upper section, the absorption peak of illite at $2200 \mathrm{~nm}$ is high $(>2208 \mathrm{~nm})$, and the SWIR-IC is smaller than 0.8; and (2) in the lower section, the absorption-peak wavelength at $2200 \mathrm{~nm}$ gradually shifts to shorter wavelength ranges $(<2203 \mathrm{~nm})$, and the SWIR-IC gradually shifts to greater values ranges (Figure 10a-c). However, the absorption peak of illite at $1900 \mathrm{~nm}$ exhibits no obvious changes.
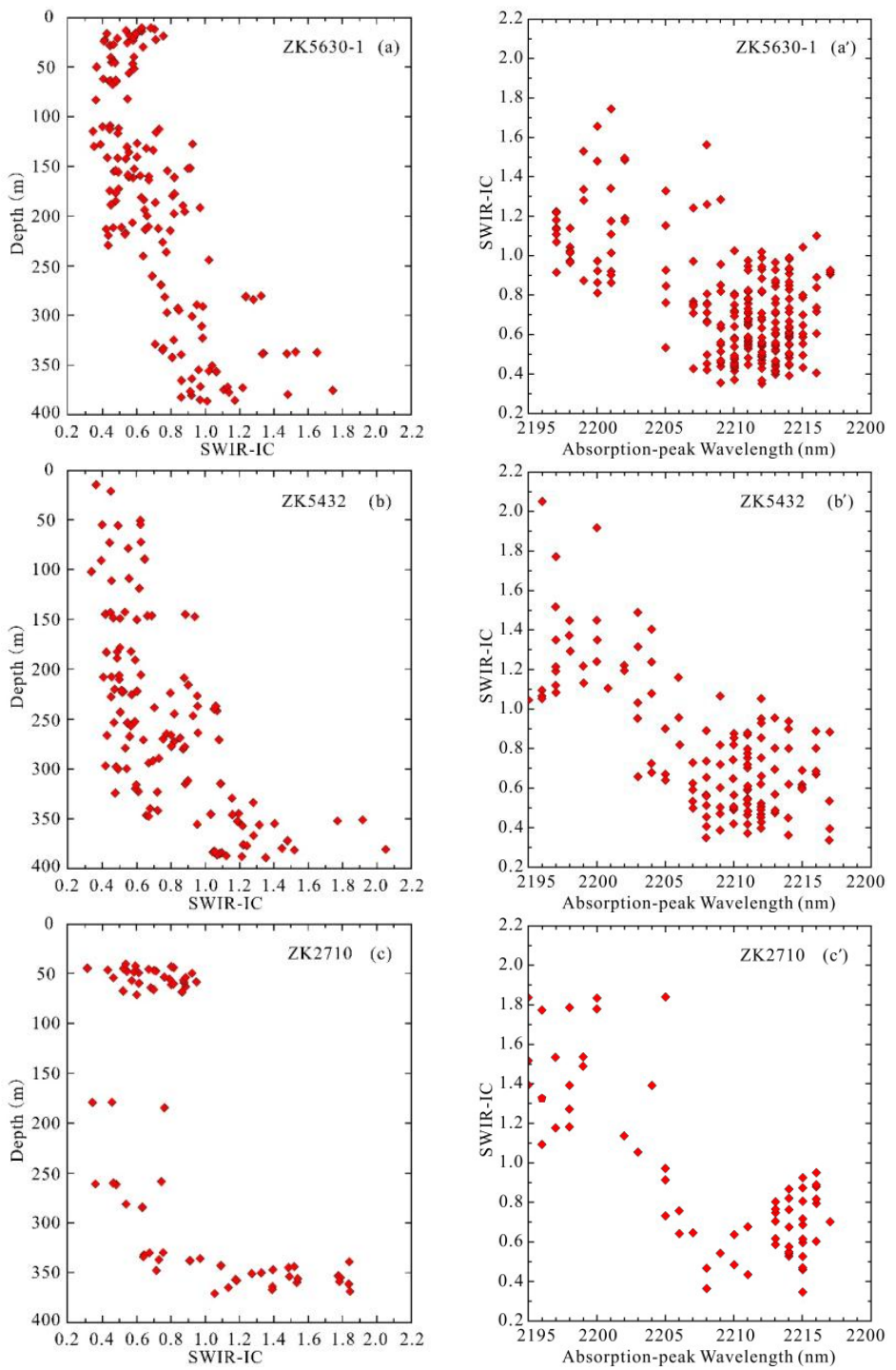

Figure 10. (a-c) SWIR-IC (1000-2500 nm) versus depth for drill holes ZK5630-1, ZK5432 and ZK2710,

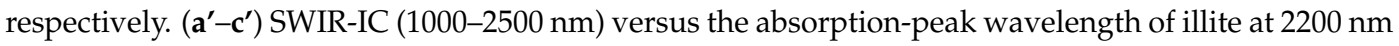
for drill holes ZK5630-1, ZK5432 and ZK2710, respectively. 
In the other drill holes, i.e., ZK5428, ZK5234, ZKQ3318, ZK3310, ZK3518 and ZK2906, the SWIR-IC values in Figure 11 were similar to those of the three drill holes described in the previous Figure 10, and the SWIR-IC values gradually increased from the upper section to the lower section of the drill holes in the Baiyanghe uranium deposit.
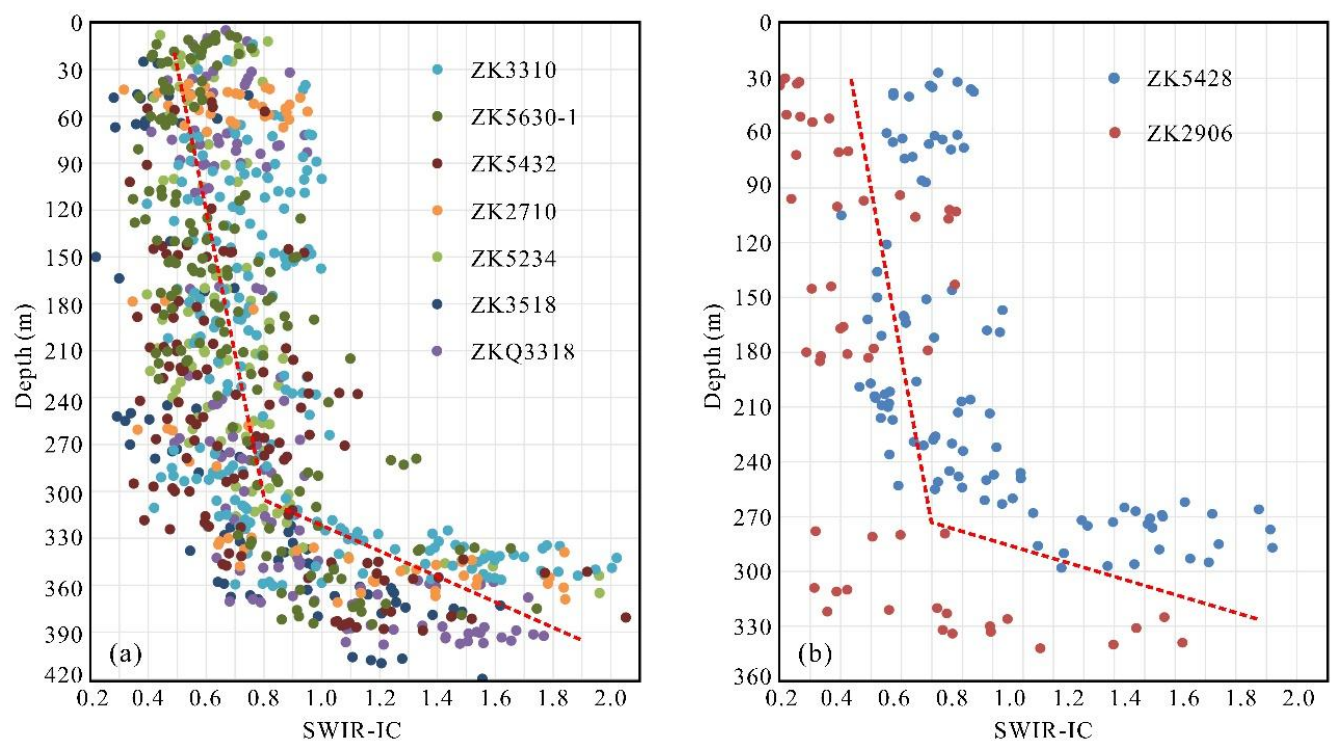

Figure 11. (a) SWIR-IC (1000-2500 nm) versus depth for drill holes ZK3310, ZK5630-1, ZK5432, ZK2710, ZK5234, ZK3518, and ZKQ3318. (b) SWIR-IC (1000-2500 nm) versus depth for drill holes ZK5428 and ZK2906.

\subsection{X-ray Diffraction Analysis of Altered Sample Rocks}

Some altered rocks were sampled and the clay minerals were analyzed by XRD (X-ray diffraction) to more accurately and thoroughly determine the typical white mica minerals (illite and muscovite) for spectral recognition in the drill cores. The alteration minerals in these samples mainly include short-wavelength illite and long-wavelength illite, and the absorption-peak wavelength of illite at $2200 \mathrm{~nm}$ is from 2196 to $2216 \mathrm{~nm}$. The XRD results of the samples are shown in Table 4.

Table 4. Analysis of clay in the altered rocks from drill cores in the deposit *

\begin{tabular}{cccccccc}
\hline \multirow{2}{*}{ Sample Number } & \multirow{2}{*}{ Altered Mineral } & \multirow{2}{*}{ Sampling Depth $(\mathbf{m})$} & \multicolumn{5}{c}{ Analysis Results (wt \%) } \\
\cline { 4 - 7 } & & & $\mathbf{S}$ & $\mathbf{I} / \mathbf{S}$ & $\mathbf{I t}$ & Kao & C \\
\hline $5630-01$ & Illite & 295 & 11 & 38 & 48 & $/$ & 3 \\
\hline $5630-02$ & Illite & 305 & 7 & 19 & 43 & $/$ & 31 \\
\hline $5630-03$ & Illite & 310 & 8 & 21 & 41 & 7 & 23 \\
\hline $5630-04$ & Illite & 320 & $/$ & 40 & 57 & 3 & $/$ \\
\hline $5630-05$ & Illite & 335 & $/$ & 40 & 57 & 3 & $/$ \\
\hline $3318-01$ & Illite, Chlorite & 382 & $/$ & 27 & 33 & $/$ & 40 \\
\hline $3318-02$ & Illite, Chlorite & 391 & $/$ & $/$ & 54 & 12 & 34 \\
\hline $3318-03$ & Illite & 398 & $/$ & $/$ & 99 & $/$ & 1 \\
\hline $3318-04$ & Chlorite & 426 & $/$ & $/$ & 6 & $/$ & 94 \\
\hline $3318-05$ & Chlorite & 437 & $/$ & $/$ & $/$ & $/$ & 100 \\
\hline $3318-06$ & Illite, Chlorite & 443 & $/$ & $/$ & 18 & $/$ & 82 \\
\hline $3318-07$ & Illite, Chlorite & 449 & $/$ & 19 & 50 & $/$ & 31 \\
\hline
\end{tabular}

* The results were tested at the Beijing Research Institute of Uranium Geology. S, Smectite; I/S, Illite/Smectite mixed-layer minerals; It, Illite; Kao, Kaolinite; C, Chlorite. 
According to Table 4, samples 5630-01-5630-05 from ZK5630-1 are mainly located from 290 to $340 \mathrm{~m}$ and contain the uranium mineralization section, where the identified altered minerals mainly include the three types of illite (short-wavelength, medium-wavelength and long-wavelength) (Figure 12a). The XRD results of these samples showed that illite and mixed-layer illite/smectite minerals were the main clay minerals, which was consistent with the altered minerals that were identified from the FieldSpec4 visible-shortwave infrared spectrometer. Moreover, samples 3318-01-3318-07 were from ZKQ3318 and were mainly located in the lower section, where the identified altered minerals were short-wavelength illite, chlorite and mixture of illite and chlorite (Figure 12b), which is also consistent with the results of the samples. Therefore, it is reasonable to classify the white mica (illite and muscovite) in the Baiyanghe uranium deposit as illite, which is supported by the geological background.
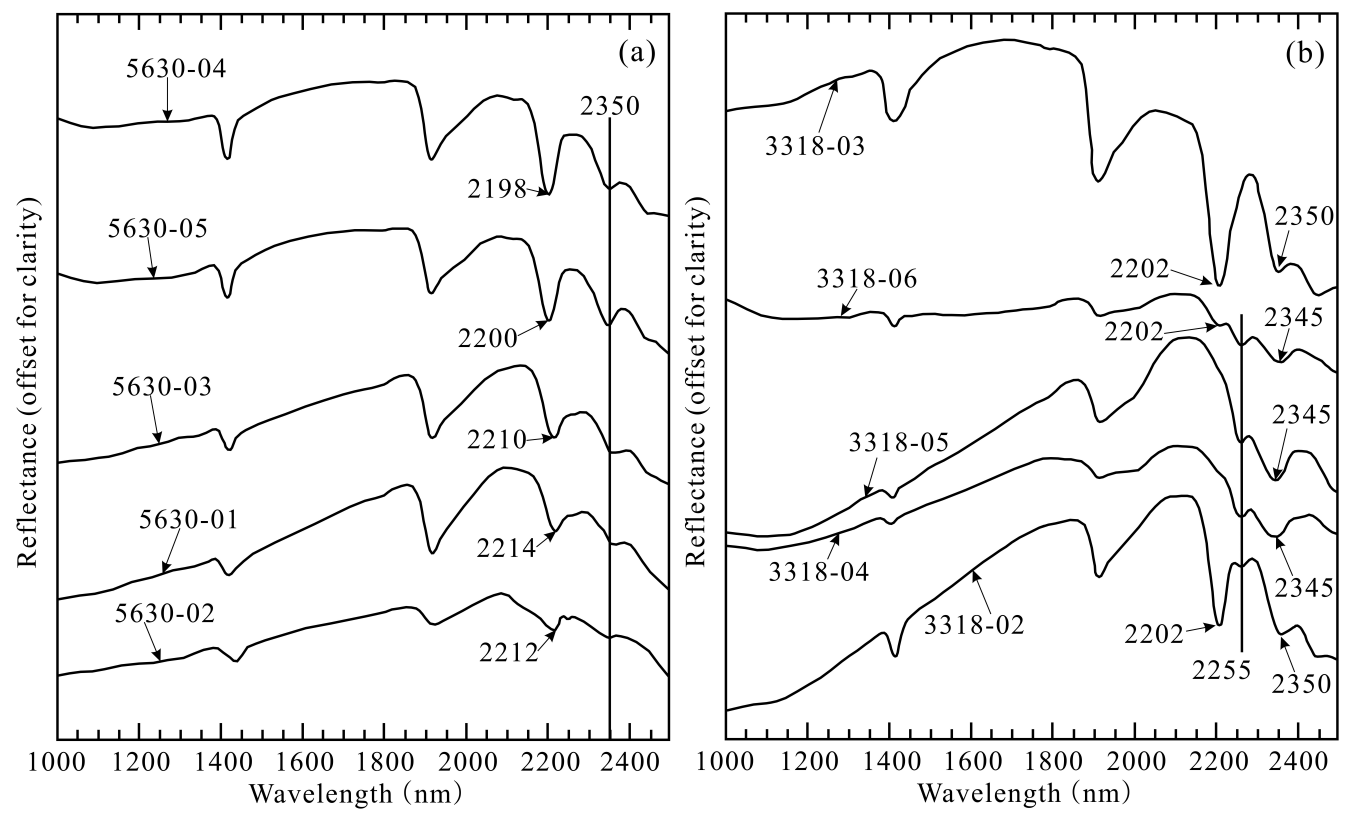

Figure 12. (a) Spectral curves (1000-2500 nm) of the samples 5630-01-5630-05 from ZK5630-1. (b) Spectral curves (1000-2500 nm) of the samples 3318-02-3318-06 from ZKQ3318.

\section{Discussion}

\subsection{P-T Characteristics of the Hydrothermal Fluid}

The Baiyanghe uranium-beryllium deposit is believed to be a hydrothermal deposit, comparable to the hydrothermal Spokane Mountain beryllium-uranium deposit (United States), in which Be-U mineralization occurred during the hydrothermal stage after the diagenetic stage [22,26]. Studies suggested that under conditions of weak or no alteration, the absorption-peak wavelength of illite at $2200 \mathrm{~nm}$ is greatly affected by the lithology of the original rock [31]. Generally, short-wavelength (Al-rich) illite is more likely to be observed in felsic rocks, and long-wavelength (Al-poor) illite is more likely to be observed in basic and intermediate-mafic rocks [13]. In ZK5432, ZK5630-1, ZK5234, ZK5428, ZK3310, ZK2710, ZKQ3318, ZK2906 and ZK3518, the upper portion of the deposit is granite porphyry and the lower section consists of tuffaceous sandstone. Thus, if the lithology is the main controlling factor, the absorption-peak wavelength of illite at $2200 \mathrm{~nm}$ is more likely to be long-wavelength (Al-poor) in the lower section and short-wavelength (Al-rich) in the upper section. However, the measurements of ZK5432, ZK5630-1, ZK5234, ZK5428, ZK3310, ZK2710, ZKQ3318, ZK2906 and ZK3518 showed the opposite trend. Therefore, the alteration structure of a long-wavelength upper section and a short-wavelength lower section that is reflected in the hyperspectral data from the drill cores ZK5432, ZK5630-1, ZK5234, ZK5428, ZK3310, ZK2710, ZKQ3318, ZK2906 and ZK3518 was mainly the result of deep hydrothermal activity rather than a variation in the lithology. Additionally, illite, with its variable 
absorption-peak wavelength at $2200 \mathrm{~nm}$, is the most widely distributed hydrothermal mineral in the Baiyanghe uranium deposit. The SWIR-IC also shows regular changes. Therefore, we must discuss the $\mathrm{P}-\mathrm{T}$ characteristics of the hydrothermal fluid in the uranium deposit, which is useful for deep mineral uranium exploration.

Generally, the absorption-peak wavelength of white mica (illite and muscovite) at $2200 \mathrm{~nm}$ is governed by the $\mathrm{Al}^{\mathrm{VI}}$ content, and changes in the $\mathrm{Al}^{\mathrm{VI}}$ content are generally caused by the replacement of different elements. As the $\mathrm{Al}^{\mathrm{VI}}$ content increases, the absorption band near $2200 \mathrm{~nm}$ gradually shifts to shorter wavelengths. Additionally, as K is replaced by Na, the absorption band near $2200 \mathrm{~nm}$ gradually shifts to shorter wavelengths [29,32-34]. Furthermore, the replacement process depends on the temperature, pressure, and $\mathrm{pH}$ properties of the fluid. Previous studies proposed that Al-poor white mica may be related to low temperatures, whereas Al-rich white mica (illite and muscovite) may be related to relatively high temperatures [35]. Liu et al. stated that the characteristic absorption wavelength of white mica minerals at $2200 \mathrm{~nm}$ was shifted to longer wavelengths, indicating that the $n$ $\left(\mathrm{Al}^{\mathrm{VI}}\right)$ content in the mica was reduced and reflecting the formation of relatively low pressures and high temperatures. Similarly, short wavelengths indicate that the $n\left(\mathrm{Al}^{\mathrm{VI}}\right)$ content in the mica was higher, reflecting the formation of relatively high pressures and low temperatures [36]. Furthermore, studies on white mica (illite and muscovite) minerals showed that the Si content increases with increasing pressure and decreases with increasing temperature in cases where the rock and mineral compositions are similar [37]. Additionally, the relationship between the Si content of white mica (illite and muscovite) and the temperature and pressure is shown in Equation (2), where $\mathrm{P}$ is the pressure $(108 \mathrm{~Pa})$ and $\mathrm{T}$ is the temperature $\left({ }^{\circ} \mathrm{C}\right)$ [38]. The absorption-peak wavelength of white mica minerals at $2200 \mathrm{~nm}$ is negatively correlated with the $\mathrm{Al}{ }^{\mathrm{VI}}$ content and positively correlated with the Si content [33]. These studies suggested that changes in absorption-peak wavelengths of white mica (illite and muscovite) at $2200 \mathrm{~nm}$ are closely related to the temperature and pressure.

$$
\mathrm{Si}=0.02146 \mathrm{P}-0.0001904 \mathrm{~T}+3.025
$$

As noted above, the SWIR-IC is an important spectral parameter for white mica (illite and muscovite) and is usually controlled by the temperature. Thus, this parameter is useful for exploration $[18,19]$. Studies have shown that the SWIR-IC values of white mica (illite and muscovite) can often indicate the center of hydrothermal fluid activity: higher SWIR-IC values correspond to higher formation temperatures and higher degrees of alteration [15,18,19].

In conjunction with previous research results, we found long-wavelength illite in the upper section of the drill holes and short-wavelength illite in the lower section in the Baiyanghe uranium deposit. Thus, the absorption-peak wavelength of illite at $2200 \mathrm{~nm}$ varies from long wavelengths to short wavelengths from the surface to the bottom of the drill holes, which indicates that the temperature and pressure of the deeper illite was greater than that of the shallower illite. Furthermore, the SWIR-IC values gradually increased from the upper section to the lower section in the Yangzhuang rock body of the Baiyanghe uranium deposit, and an obvious boundary was observed near the fault and fracture zone.

The SWIR-IC values beneath the boundary were greater than those above the boundary, which indicates that the temperature of the short-wavelength illite in the lower section was higher than that in the upper section of the rock body and that the center of the hydrothermal fluid activity was located in the lower section close to the fault and fracture zone. These results show that the temperature of the fluid gradually changed from relatively high temperatures at depth to relatively low temperatures in the upper section in the granite porphyry. Additionally, the hydrothermal fluids directly cut through the fault and fracture zone from the deeper areas and continued to flow and vary at shallower depths, as observed in nine drill holes. Thus, the fluids experienced continuous fluid alteration.

We infer that the hydrothermal activity that led to the alteration zonation in the drill holes ZK5432, ZK5630-1, ZK5234, ZK5428, ZK3310, ZK2710, ZKQ3318, ZK2906 and ZK3518 was likely characterized by relatively high temperatures and high pressures at depth and relatively low temperatures and low 
pressures near the surface in the Baiyanghe uranium deposit. The vicinity of the fault and fracture zone was the center of hydrothermal fluid activity or mineralization.

\subsection{Alteration and Uranium Exploration}

The granite porphyry in the Baiyanghe uranium deposit is interspersed with a large number of diabase and diorite veins that formed at $309 \mathrm{Ma}$. The intrusion of the intermediate-basic dikes and mineralization occurred after the formation of the granite porphyry, and previous studies suggested that the metallogenic age of the asphaltic uranium deposit was similar to the intrusion age of the diabase veins [23]. Mineralization occurred after the formation of the granite porphyry, when the region had been uplifted above sea level $[26,39]$. U-Pb isotopic dating of the asphaltic uranium in the Baiyanghe deposit suggested that tectonic movement and hydrothermal activity may have occurred during the Late Cretaceous and Paleogene after the Xuemisitan region entered the inland evolution stage [40]. Thus, the Baiyanghe deposit has an obvious hydrothermal mineralization origin, and the hydrothermal alteration was closely related to the uranium mineralization, which was generally identified near the fault and fracture zone.

The wall rock experienced many types of alteration, including hematitization, hydromicazation (altered name in geological significance, equivalent to illite alteration in remote sensing), fluoritization, silicification, chloritization and carbonatization at the ground surface of the Baiyanghe uranium deposit, and the hematitization, hydromicazation (illite alteration) and purple-black fluoritization were closely related to the uranium mineralization [9,40]. Based on FieldSpec4 spectrometer measurements in the field, we found that short-wavelength illite, medium-wavelength illite (with an absorption-peak wavelength of less than $2212 \mathrm{~nm}$ ), hematite and chlorite were abundant near the uranium mineralization zone in the contact zone between the upper Carboniferous microcrystalline granite porphyry and the intermediate-basic volcanic rocks of the Upper Devonian Taerbarhata Formation in the northern section of the deposit, where purple-black fluorite was also present (Figure 13a,b).
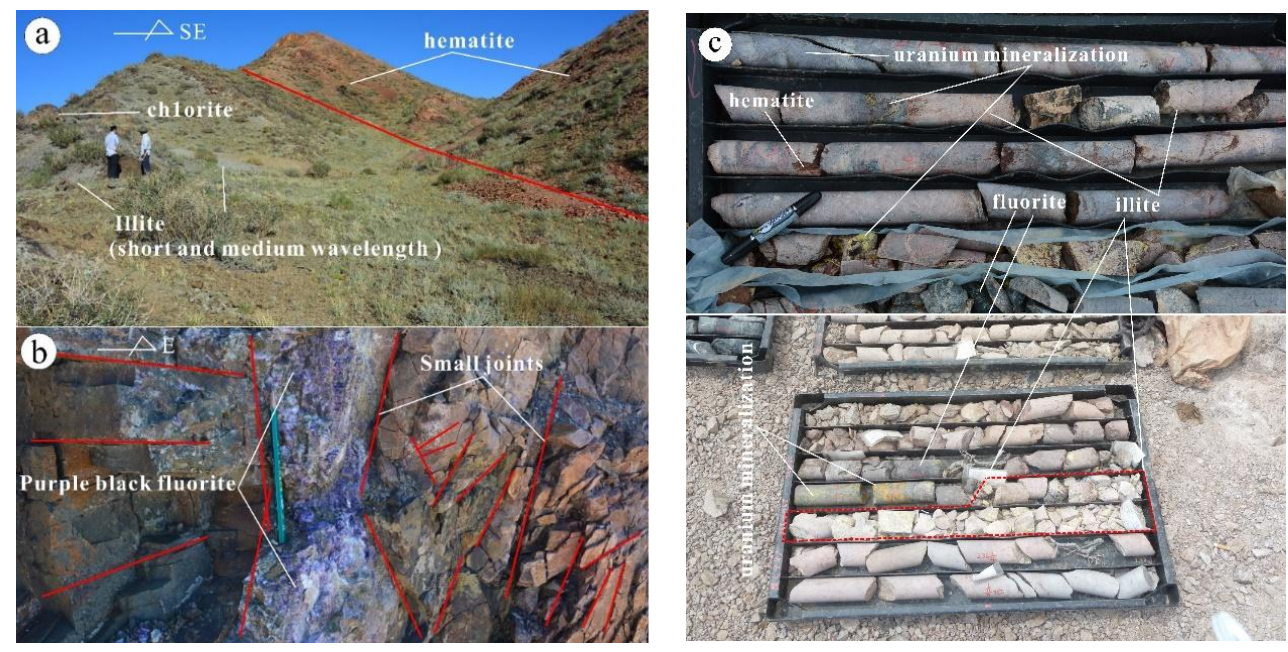

Figure 13. (a) Field photograph of alteration minerals, including illite (short-wavelength and medium-wavelength) and hematite. (b) Field photograph of purple-black fluorite in the Baiyanghe uranium deposit. (c) Picture of illite, fluorite, hematite and uranium mineralization in cores from the drill holes in the Baiyanghe uranium deposit.

Furthermore, the degree of development of short-wavelength illite, medium-wavelength illite (with an absorption-peak wavelength of less than $2212 \mathrm{~nm}$ ) and hematite was closely related to the uranium mineralization: the wider the alteration zone of short-wavelength illite and hematite, the better the uranium mineralization in the contact zone in the northern section of the deposit. 
Therefore, the minerals illite (short- and medium-wavelength), hematite and fluorite can be used as uranium-prospecting indicators at the surface of the uranium ore deposit $[25,40]$.

Similarly, data from the drill holes in the Baiyanghe uranium deposit showed that the alteration minerals short- and medium-wavelength illite (with an absorption-peak wavelength of less than $2212 \mathrm{~nm}$ ), hematite and chlorite also occurred near the uranium ore body between the upper granite porphyry and the underlying tuff in the Upper Devonian Taerbarhata Formation (Figure 13c), where fluorite was also present. The stronger the hematitization, fluoritization and illite alteration, the higher the $\mathrm{U}_{\gamma}$ values of the uranium ore became.

Asphaltic uranium ore is the primary form of uranium in the Baiyanghe deposit, and the formation time of this ore corresponds to the timing of hydrothermal uranium mineralization. The Yangzhuang rock body and the surrounding rock experienced a number of tectonic events, and multiple hydrothermal uranium mineralization events may have occurred, resulting in the scattered and small-scale distribution of uranium ore bodies in the Baiyanghe deposit [40]. The ore-forming hydrothermal fluids in the deposit may have originated from great depths and may have risen along the Chagantaolegai-Bayinbulake Fault, which represented the center of hydrothermal fluid activity. This hydrothermal activity resulted in wall-rock alteration, uranium precipitation and mineralization [41].

Thus, the Baiyanghe uranium deposit has an obvious hydrothermal mineralization origin, and the hydrothermal alteration was closely related to uranium mineralization, which was generally identified in the transitional fault and fracture zone between the middle section, mainly comprising medium-wavelength illite and hematite, and the lower section, mainly comprising short-wavelength illite and chlorite.

Hematitization is mainly distributed in the uranium bodies and the main near-mine alteration in the Baiyanghe uranium deposit. This hematitization likely occurred earlier than the uranium mineralization and provided a good chemical environment for uranium mineralization [41,42]; thus, hematitization promoted uranium mineralization. Based on the alteration mineral assemblages in the Baiyanghe uranium deposit, the relevant chemical process during uranium mineralization is shown in Equation (3), where $\mathrm{U}_{3} \mathrm{O}_{8}$ represents asphaltic uranium ore and $\mathrm{Fe}_{2} \mathrm{O}_{3}$ represents hematite [42].

$$
\mathrm{UO}_{2}(\mathrm{OH})_{2}+2 \mathrm{Fe}(\mathrm{OH})_{2}+\mathrm{H}_{2} \mathrm{O} \rightarrow \mathrm{U}(\mathrm{OH})_{4}+2 \mathrm{Fe}(\mathrm{OH})_{3} \rightarrow \mathrm{U}_{3} \mathrm{O}_{8}+\mathrm{Fe}_{2} \mathrm{O}_{3}
$$

Fluoritization is also an important type of hydrothermal alteration and was closely related to the uranium mineralization [39-43]. Furthermore, illite alteration (short- and medium-wavelength), which was equivalent to hydromicazation, occurred because of hydrothermal alteration. During this process, mixed-layer illite/smectite minerals could adsorb U during the early stages of mineralization. During this metallogenic hydrothermal process, the $U$ that was adsorbed by mixed-layer illite/smectite minerals was released, forming a uranium ore body [44]. Thus, illite alteration was a very important form of hydrothermal alteration for uranium mineralization. Consequently, the uranium mineralization sections in the drill cores of the Baiyanghe uranium deposit contain relatively high amounts of shortand medium-wavelength illite, hematite and fluorite.

Moreover, in the Xuemisitan area, the Chagantaolegai-Bayinbulake Fault and the volcanic system, which included Yangzhuang, Xuemisitan, the Qiyi work area, the Shiyue work area, and Mamente, are favorable for uranium mineralization, where similar alteration developed including hematitization, illite alteration, fluoritization, silicification, chloritization with carbonatization, with many uranium mineralization areas forming [6,7]. We conclude that illite alteration (hydromicazation), hematitization and fluoritization were closely related to the uranium mineralization in the Baiyanghe uranium deposit and that the resulting minerals can be used as uranium-prospecting indicators during the exploration of the deeper sections of the Xuemisitan area. However, the geologic origin of this uranium mineralization requires further study. 


\section{Conclusions}

In this paper, a FieldSpec4 ground-based spectrometer was used to obtain hyperspectral alteration information from drill cores from the Baiyanghe uranium deposit, Xinjiang. The following conclusions were reached.

(1) The hyperspectral alteration characteristics of the drill cores from the deeper sections of the Baiyanghe deposit were measureable. The alteration mineral assemblages could be divided into three sections: (1) an upper section, which contains long-wavelength illite and minor hematite, limonite, and montmorillonite; (2) a middle section, which contains three types of illite (long-, short- and medium-wavelength) and minor montmorillonite, carbonate, hematite and limonite; and (3) a lower section, which contains short-wavelength illite, chlorite, and carbonate.

(2) The variations in the absorption-peak wavelength (1000-2500 nm) of illite at $2200 \mathrm{~nm}$ [11] and the SWIR-IC (1000-2500 nm) values of the nine drill cores revealed that the hydrothermal fluid was likely characterized by relatively high temperatures and high pressures at greater depths and relatively low temperatures and low pressures at shallower depths in the Baiyanghe uranium deposit, and that the vicinity of the fault and fracture zone represented the center of hydrothermal fluid activity or mineralization.

(3) The hydrothermal alteration was closely related to the uranium mineralization. The alteration minerals illite (short- and medium-wavelength), hematite and fluorite could be used as surface indicators of uranium at depth and at-depth indicators of the contents of these same minerals in the Baiyanghe uranium deposit in the Xuemisitan area to guide deep uranium exploration.

Acknowledgments: This study was financially supported by the National Natural Science Foundation of China (Grant No. 41572189), the Strategic Priority Research Program (B) of Chinese Academy of Sciences (Grant No. XDB18000000), and the Concentrated Research Development Project of the China National Nuclear Corporation (Comprehensive application study on hyperspectral remote sensing for uranium and multi-metal ore exploration, Grant No. YLTY1604). We thank Jun-Ting Qiu for providing valuable ideas; Lei Zhang, the leader of Geological Team 216, for providing help and support for the data collection from the drill cores and in the field; Qian Zhang, Shu Meng and Hong-Cheng Liu for assisting with the collection of hyperspectral data from the drill cores; the editors for their editorial handling; and four anonymous reviewers for their comments and suggestions.

Author Contributions: Qing-Jun Xu wrote this paper and performed the fieldwork. Shao-feng Liu provided much help and many valuable suggestions, and great help to the language editing of the article. Fa-wang Ye provided some key ideas and suggestions. Zhi-Xin Zhang wrote the program that computed the SWIR-IC. Chuan Zhang measured the gamma intensities of the rocks.

Conflicts of Interest: The authors declare no conflicts of interest.

\section{References}

1. Yang, W.L.; Mostafa, F.; Li, Y.L.; Wang, M.; Zhou, J. Characteristics of fluid inclusions and fluorite of Baiyanghe beryllium deposit in Western Junggar. Xinjiang Geol. 2014, 32, 82-86. (In Chinese)

2. Mao, W.; Wang, G.; Li, X.F.; Wang, M.; Xiao, R. A study of fluid inclusions in Baiyanghe U-Be deposit, Xinjiang. Miner. Depos. 2013, 32, 1026-1034. (In Chinese)

3. Zhang, X.; Zhang, H. Geochemical characteristics of the ore-forming fluid and ore genesis of the Baiyanghe Be-U deposit, Xinjiang, China. Geochimica 2013, 42, 143-152. (In Chinese)

4. Xiao, Y.D.; Huang, J.H.; Wang, Z.; Wang, S.C.; Zhou, Y.B.; Li, Q.D. Spatial distribution of uranium and beryllium ore bodies in the Baiyanghe deposit, Hebukesaier county, Xinjiang. West-China Explor. Eng. 2011, 9, 123-126. (In Chinese)

5. Tong, X.H.; Zhang, W.S.; Shi, Z.L.; Li, Y.L. Characteristics of ore-controlling structures in the Baiyanghe uranium deposit, Xinjiang. Miner. Depos. 2012, 31, 219-220. (In Chinese)

6. Lu, K.G.; Wang, G.R.; Yin, S.; Li, X.L. Discussion on the interpretation of volcanic texture from ETM+ map and uranium mineralization. In Proceedings of the Academic Annual Meeting of China Nuclear Society, Beijing, China, Progress Report on Nuclear Science and Technology, Beijing, China, 18-20 November 2009. (In Chinese) 
7. Qiu, J.T.; Zhang, C.; Hu, X. Integration of concentration-area fractal modeling and spectral angle mapper for ferric iron alteration mapping and uranium exploration in the Xiemisitan area, NW China. Remote Sens. 2015, 7, 13879-13891. [CrossRef]

8. Du, J.; Zhu, M.Y.; Wang, M. Application of integrated geophysical methods in the exploration of Baiyanghe uranium deposit, Xinjiang. Miner. Explor. 2013, 4, 191-196. (In Chinese)

9. Xiu, X.Q.; Fan, H.H.; Ma, H.F.; Yi, L.S. The wall rock alteration and its geochemical characteristics of Baiyanghe uranium and beryllium deposit, Xinjiang. Uranium Geol. 2011, 27, 215-220. (In Chinese)

10. Huang, Q.; Zhu, Y.F. Geological characteristics of volcanic-type beryllium in the Baiyanghe deposit, Xinjiang. Miner. Depos. 2012, 31, 291-292. (In Chinese)

11. Hunt, G.R.; Salisbury, J.W.; Lenhoff, C.H. Visible and Near-infrared Spectra of Minerals and Rocks: VII. Acidic Igneous Rocks. Mod. Geol. 1973, 4, 217-224.

12. Yang, K.; Browne, P.R.L.; Huntington, J.F.; Walshe, J.L. Characterising the hydrothermal alteration of the Broadlands-Ohaaki geothermal system, New Zealand, using short-wave infrared spectroscopy. J. Volcanol. Geotherm. Res. 2001, 106, 53-65. [CrossRef]

13. Kruse, F.A. Identification and mapping of minerals in drill core using hyperspectral image analysis of infrared reflectance spectra. Int. J. Remote Sens. 1996, 17, 1623-1632. [CrossRef]

14. Sun, Y.Y.; Seccombe, P.K.; Yang, K. Application of short-wave infrared spectroscopy to define alteration zones associated with the Elura zinc-lead-silver deposit, NSW, Australia. J. Geochem. Explor. 2011, 73, 11-26. [CrossRef]

15. Xu, Q.S.; Guo, J.; Liu, Y.; Huang, S.F.; Li, Q.P.; Chen, Y.S. Application of shortwave infrared spectrum mineral analyser (BJKF-1) to alteration mineral mapping at Panan, Tibte. Geol. Explor. 2011, 47, 107-112. (In Chinese)

16. Hunt, G.R.; Salisbury, J.W. Visible and near-infrared spectra of minerals and rocks: I. Silicate. Mod. Geol. 1970, 1, 283-300.

17. Yang, K.; Lian, C.; Huntington, J.F.; Peng, Q.; Wang, Q. Infrared spectral reflectance characterization of the hydrothermal alteration at the Tuwu Cu-Au deposit, Xinjiang, China. Miner. Depos. 2005, 40, 324-336. [CrossRef]

18. Chang, Z.; Hedenquist, J.W.; White, N.C.; Cooke, D.R.; Roach, M.; Deyell, C.L.; Garcia, J.; Gemmell, J.B.; McKnight, S.; Cuison, A.L. Exploration tools for linked porphyry and epithermal deposits: Example from the Mankayan intrusion-centered Cu-Au district, Luzon, Philippines. Econ. Geol. 2011, 106, 1365-1398. [CrossRef]

19. Yang, Z.M.; Hou, Z.Q.; Yang, Z.S.; Qu, H.C.; Li, Z.Q.; Liu, Y.F. Application of short wavelength infrared (SWIR) technique in exploration of poorly eroded porphyry $\mathrm{Cu}$ district: A case study of Niancun ore district, Tibet. Miner. Depos. 2012, 31, 699-717. (In Chinese)

20. Guo, N.; Guo, K.; Zhang, T.T.; Liu, T.H.; Hu, B.; Wang, C.W. Hydrothermal alteration distribution model of the Jiama (Gyama) copper-polymetallic deposit based on shortwave technique. Acta Geosci. Sin. 2012, 4, 641-653. (In Chinese)

21. Dong, L.H.; Feng, J.; Liu, D.Q.; Tang, Y.L.; Qu, X.; Wang, K.Z.; Yang, Z.F. Research for classification of metallogenic unit of Xinjiang. Xinjiang Geol. 2010, 28, 1-15. (In Chinese)

22. Wang, M.; Li, X.F.; Wang, G.; Li, Y.L.; Shi, Z.L.; Lu, K.G. Geological characteristics of Baiyanghe beryllium-uranium deposits in Xuemisitan volcanic belt. Xinjiang Miner. Explor. 2012, 3, 34-40. (In Chinese)

23. Chen, J.Y.; Fan, H.H.; Gu, D.Z. Study on the metallogenic chronology of the large uranium beryllium deposit in the Baiyanghe area, Xinjiang: constraints from the Sm-Nd isotopic age of fluorite. Acta Petrol. Sin. 2015, 89, 1-2. (In Chinese)

24. Wang, M.; Wang, G.; Li, X.F.; Shi, Z.L.; Li, Y.L.; Lu, K.G. Analysis on the controlling factors of uranium polymetallic metallogenic in the south of Xuemisitan volcanic belt. Xinjiang. Xinjiang Geol. 2013, 31, 71-75. (In Chinese)

25. Xiao, Y.D. Study on Genesis of Baiyanghe Uranium-Beryllium Deposit in Hebukeser, Xinjiang. Master's Thesis, Xinjiang University, Urumqi, Xinjiang, China, 2011.

26. Zou, T.R.; Li, Q.C. Rare and Rare Earth Metal Deposits in Xinjiang, China; Geological Publishing House: Beijing, China, 2006; pp. 1-284. (In Chinese)

27. Duke, E.F.; Lewis, R.S. Near infrared spectra of white mica in the Belt Supergroup and implications for metamorphism. Am. Mineral. 2010, 95, 908-920. [CrossRef] 
28. Van Ruitenbeek, F.J.A.; Cudahy, T.J.; van der Meer, F.D.; Hale, M. Characterization of the hydrothermal systems associated with Archean VMS-mineralization at Panorama, Western Australia, using hyperspectral, geochemical and geothermometric data. Ore Geol. Rev. 2012, 45, 33-46. [CrossRef]

29. Carsten, L. Short Wave Infrared Functional Groups of Rock Forming Minerals; Report No. EP115222; CSIRO, Earth Science and Resource Engineering: Kensington, Australia, 2011; pp. 1-14.

30. Jones, S.; Herrmann, W.; Gemmell, B. Short wavelength infrared spectral characteristics of the HW horizon: Implications for exploration in the Myra Falls volcanic-hosted massive sulfide camp, Vancouver Island, British Columbia, Canada. Econ. Geol. 2005, 100, 273-294. [CrossRef]

31. Hunt, G.R.; Salisbury, J.W.; Lenhoff, C.H. Visible and Near-infrared Spectra of Minerals and Rocks: IX. Basic and Ultrabasic Igneous Rocks. Mod. Geol. 1974, 5, 15-22.

32. Post, J.L.; Noble, P.N. The near-infrared combination and frequencies of dioctahedral smectites, micas, and illites. Clays Clay Miner. 1993, 41, 639-644. [CrossRef]

33. Herrmann, W.; Blake, M.; Doyle, M.; Huston, D.; Kamprad, J.; Merry, N.; Pontual, S. Short wave length infrared (SWIR) spectral analysis of hydrothermal alteration zones associate with base metal sulfide deposits at Rosebery and Western Tharsis, Tasmania and Highway-Reward, Queensland. Econ. Geol. 2001, 74, 1613-1629.

34. Liang, S.; Gan, F.; Yan, B.; Wang, R.S.; Yang, S.M.; Zhang, Z.J. Relationship between composition and spectral feature of muscovite. Remote Sens. Land Resour. 2012, 94, 111-115.

35. Yang, K.; Huntington, J.F.; Boardman, J.W.; Mason, P. Mapping hydrothermal alteration in the Comstock mining district, Nevada, using simulated satellite-borne hyperspectral data. Aust. J. Earth Sci. 1999, 46, 915-922. [CrossRef]

36. Liu, S.W.; Yan, B.K.; Gan, F.P.; Yang, S.M.; Wang, R.S.; Wang, Q.H. An analysis of spectral features variation of sericite and the extraction of geologic genesis information by using imaging spectroscopic technique. Remote Sens. Land Resour. 2006, 2, 46-50. (In Chinese)

37. Wei, C.; Powell, R. Calculated phase relations in high-pressure Metapelites in the system NKFMASH $\left(\mathrm{Na}_{2} \mathrm{O}-\mathrm{K}_{2} \mathrm{O}-\mathrm{FeO}-\mathrm{MgO}-\mathrm{Al}_{2} \mathrm{O}_{3}-\mathrm{SiO}_{2}-\mathrm{H}_{2} \mathrm{O}\right)$. J. Petrol. 2004, 45, 183-202. [CrossRef]

38. Massonne, H.-J.; Chopin, C. P-T history of the Gran Paradiso (Western Alps) metagranites based on phengite geobarometry. Geol. Soc. Lond. Spec. Publ. 1989, 43, 545-549. [CrossRef]

39. Han, B.F.; He, G.Q.; Wang, S. The nature of post-collisional mantle magma underplating, and the basement of the Junggar basin. China Sci. D. 1999, 29, 16-21. (In Chinese)

40. Yi, L.S.; Fan, H.R.; Zhai, M.G.; Li, Y.X.; Ma, H.F.; Tian, J.J. Fluorite Sm-Nd isoshron and pitchblende U-Pb dating in the Baiyanghe Be-U deposit, Xinjiang and their geological significances. Acta Petrol. Sin. 2016, 32, 2099-2110. (In Chinese)

41. Xiao, G.X.; Ma, H.F.; Li, G.H. Geochemistry and alteration characteristics of the wall rock and its relationship with uranium mineralization in the Baiyanghe rock body. Appl. Acta Miner. Sin. 2015, 1, 171. (In Chinese)

42. Zhou, Y.; Song, H.; Zhang, C.J.; Wang, G. Study on the relationship between uranium mineralization and wall rock alteration in the Baiyanghe deposit, Xinjiang. Acta Miner. Sin. 2015, S1, 374. (In Chinese)

43. Zeng, W.L.; He, Y.H.; Zhang, L.G.; Chen, Y.L.; Shao, Y.J. A study on wall-rock alteration of uranium mineralization in Taoshan ore-filed. Geol. Explor. 2010, 1, 1-9. (In Chinese)

44. Wen, Z.J.; Du, L.T.; Liu, Z.Y. Relationship between hydromicatization and uranium mineralization in the Xiangshan orefield. Miner. Depos. 2000, 3, 257-263. (In Chinese)

(c) 2017 by the authors. Licensee MDPI, Basel, Switzerland. This article is an open access article distributed under the terms and conditions of the Creative Commons Attribution (CC BY) license (http:/ / creativecommons.org/licenses/by/4.0/). 